\title{
Guyana: Enhanced Initiative for Heavily Indebted Poor Countries- Completion Point Document
}

This paper was prepared by staff of the International Monetary Fund and the World Bank in connection with the Executive Board's consideration of Guyana's progress under the Enhanced Initiative for Heavily Indebted Poor Countries. It is based on the information available at the time it was completed on November 26, 2003. The views expressed in this document are those of the staff team and do not necessarily reflect the views of the government of Guyana or the Executive Board of the IMF.

The policy of publication of staff reports and other documents by the IMF allows for the deletion of market-sensitive information.

To assist the IMF in evaluating the publication policy, reader comments are invited and may be sent by e-mail to publicationpolicy@imf.org.

Copies of this report are available to the public from

International Monetary Fund • Publication Services

700 19th Street, N.W. • Washington, D.C. 20431

Telephone: (202) 6237430 • Telefax: (202) 6237201

E-mail: publications@imf.org • Internet: http://www.imf.org

Price: $\$ 15.00$ a copy

\section{International Monetary Fund Washington, D.C.}





\title{
INTERNATIONAL MONETARY FUND AND \\ THE INTERNATIONAL DEVELOPMENT ASSOCIATION
}

\author{
GUYANA
}

\section{Completion Point Document under the Enhanced Heavily Indebted Poor Countries (HIPC) Initiative}

\author{
Prepared by the Staffs of the International Monetary Fund and \\ The International Development Association ${ }^{1}$
}

November 26, 2003

HIPC completion point. The staffs of the IMF and IDA consider that Guyana has broadly met the completion point conditions under the enhanced HIPC Initiative: a track record of policy implementation has been established through the completion of the first review under the PRGF in September and good progress toward meeting the conditions of the second review due in February 2004; overall progress in poverty reduction has been broadly acceptable as indicated by increased poverty-related expenditures and improvements in key social indicators since 2000; and most of the floating completion point conditions have been met. The completion point Board meetings will be held after the government has granted a 2003 wage increase for core civil servants in line with the PRGF program, and has enacted an organic budget law, and are tentatively scheduled for December 15 (IMF) and December 16 (IDA).

Waiver request. The staffs support the authorities' request for waivers of two of the floating completion point conditions on civil service reform, as compensatory measures have been taken. The requirement to downsize 1,000 core civil servants has been compensated by more than 2,500 layoffs elsewhere in the public sector. The completion of a list of job descriptions and design of a performance appraisal system has been replaced by the initiation of a comprehensive civil service reform with IDB support. Moreover, the government has formalized a hiring freeze in the core civil service until the IDB program is operational in 2005 and has committed to grant 2003 wage increases to core civil service workers consistent with the macroeconomic framework.

Creditor assurances for the HIPC. Financing assurances regarding enhanced HIPC Initiative assistance for Guyana represent about 81 percent of the total assistance approved at the time of the decision point, which is sufficient for the completion point and for the IMF to disburse its assistance.

Future debt sustainability. Guyana qualifies for enhanced HIPC assistance under the fiscal window. At end 2003, after enhanced HIPC relief, the ratio of the NPV of debt to central government revenues is estimated at 213 percent, 37 percent lower than the fiscal threshold. While the ratio rises in the short run associated with the large investment in the sugar sector, it levels out at about 150 percent in 2022. Sensitivity analysis highlights that the ratio could be as high as 200 percent in 2022 if the sugar price that Guyana receives from its current preferential markets is halved in 2007 once liberalization of the sector takes place.

\footnotetext{
${ }^{1}$ Approved by Anoop Singh and Juha Kähkönen (IMF), and David De Ferranti and Gobind Nankani (IDA).
} 


\section{Contents}

I. Introduction

II. Assessment of Requirements for Reaching the Completion Point ............................... 7

A. Implementation of the Poverty Reduction Strategy .......................................... 7

B. Broad-Based Growth and Maintenance of Macroeconomic Stability .................... 8

C. Stronger Institutions and Better Governance .....................................................10

D. Investment in Human and Physical Capital .........................................................11

E. Improved Tracking of Poverty and Regional Poverty Programs ...........................13

F. Public Enterprises, Taxation, and Civil Service Reforms...................................14

III. Delivery of Debt Relief and Medium-Term Sustainability............................................16

A. Status of Creditor Participation and Projected Profile of Relief........................... 17

B. Long-Term Macroeconomic Framework ...........................................................19

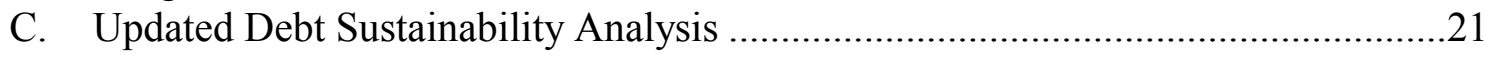

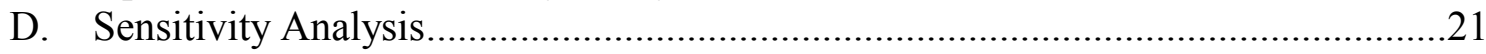

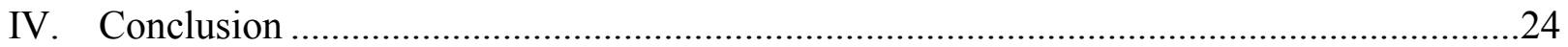

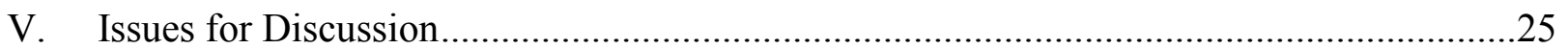

Boxes

1. HIPC Completion Point Status ......................................................................... 5

2. The Broad Parameters of the 2003 Tax Reform ...................................................... 15

3. Macroeconomic Assumptions Underlying the Debt Sustainability Analysis ....................20

Figures

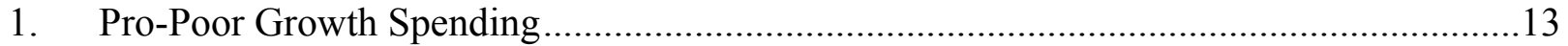

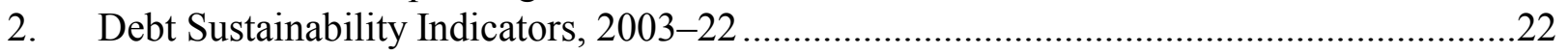

Text Tables

1. Selected Social Indicators: Guyana and Comparators, 2001 ..................................... 8

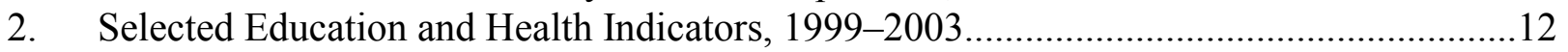

Tables

1. Estimated Assistance at Enhanced Decision Point (Amended) ....................................26

2. Net Present Value of External Debt Outstanding as of End-December 1998....................27

3. Selected Economic and Financial Indicators .........................................................28

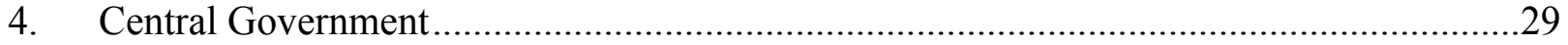

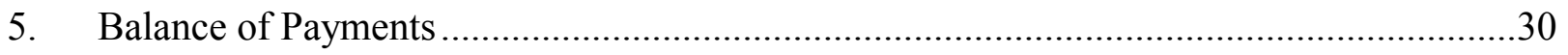

6. Nominal and Net Present Value of External Debt Outstanding at End-2002 ...................31

7. Comparison of Discount Rate and Exchange Rate Assumptions at End-1998

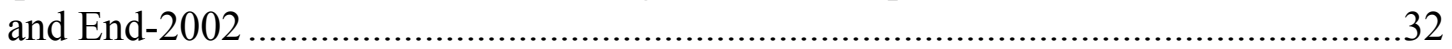

8. Comparison of Net Present Value of External Public Debt Between Decision Point

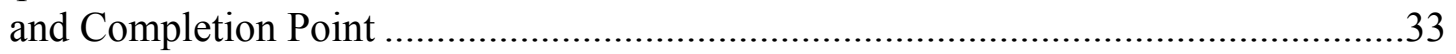

9. Net Present Value of External Debt, 2002-22 ........................................................34 
10. External Debt Service After Full Implementation of Debt-Relief Mechanisms ................35

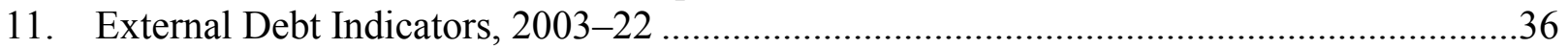

12. Status of Creditor Participation Under Original HIPC Initiative .......................................

13. Status of Creditor Participation Under Enhanced HIPC Initiative.....................................38

14. Delivery of IMF Assistance Under the HIPC Initiative ..................................................39

15. Possible Delivery of IDA Assistance Under the HIPC Initiative.....................................40

16. Paris Club Creditors' Delivery of Debt Relief under Bilateral Initiatives Beyond

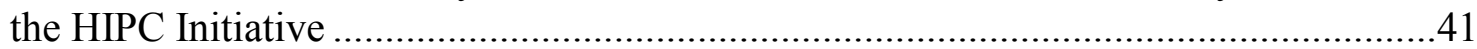

17. HIPC Initiative: Status of Country Cases Considered Under the Initiative .......................42

18. External Debt Indicators and Sensitivity Analysis, 2003-22 .....................................43

Appendices

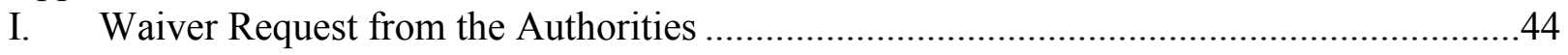

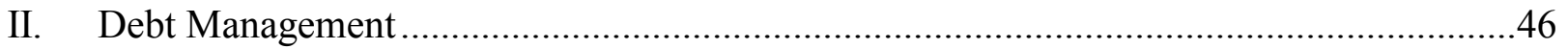




\section{INTRODUCTION}

1. In September 2002, some Directors noted that the completion point could be reached at the time of the first review of the current Poverty Reduction and Growth Facility (PRGF)-supported program, provided the conditions defined at the decision point $^{2}$ are fulfilled (Box 1). Almost all triggers have now been met, including the preparation of a consultative poverty reduction strategy paper (PRSP) that outlines the government's plans to use HIPC debt relief to reduce poverty. ${ }^{3}$ The authorities have requested (Appendix I) that two pending triggers be waived - namely, the requirements to lay-off 1,000 core civil servants, and to complete a list of job descriptions and design a performance appraisal system in connection with civil service reform. The staffs support the authorities' waiver requests based on significant progress made in implementing a more comprehensive civil service reform program with support from the IDB (see Box 1 for more details); on the progress with employment downsizing in the non-government public sector; and on other measures aimed at advancing civil service reform and controlling the public sector wage bill. On this basis, and provided that the pending compensatory measures related to core civil service wage increase and enactment of the organic budget law (see below) are implemented, the staffs recommend that the Executive Boards of the IDA and IMF agree that Guyana has reached the completion point under the enhanced HIPC Initiative.

\section{Guyana has received substantial amounts of debt relief under the HIPC}

Initiative. The Executive Boards of the IMF and IDA agreed in May 1999 that Guyana had met the requirements of the completion point under the original HIPC Initiative, qualifying it for US\$256 million in debt relief in net present value (NPV) terms (Table 1). This reduced the NPV of Guyana's external debt to the required threshold of 280 percent of average central government revenues as of end-1997. Paris Club bilateral creditors agreed in June 1999 to grant the required relief under Lyons terms (a stock of debt operation with an 80 percent NPV reduction on eligible debt).

3. Subsequently, the Executive Boards agreed in November 2000 that Guyana had reached the decision point under the enhanced HIPC Initiative. This qualified it for further relief of about US\$329 million in NPV terms, so as to bring its debt to revenue ratio below the new threshold of 250 percent as of end-1998. ${ }^{4}$ The Boards also agreed to provide interim debt relief to Guyana until the new completion point was reached. As a result, Guyana has received SDR15.4 million from the IMF and US\$6.5 million from IDA as enhanced HIPC interim relief since 2000, which was complemented by a decision by the Inter-American Development Bank (IDB) in September 2002 to give interim relief for about US\$16.5 million, as of end-2003.

\footnotetext{
${ }^{2}$ See www.imf.org and IDA's Report No. P7394-GUY (October 26, 2000).

${ }^{3}$ www.imf.org and IDA/SecM202-0476.

${ }^{4}$ Guyana qualified for enhanced HIPC assistance under the fiscal window with an NPV of external debt to revenue ratio of 417 percent.
} 
$-5-$

\begin{tabular}{|c|c|c|c|c|c|c|c|c|c|c|c|c|c|c|}
\hline 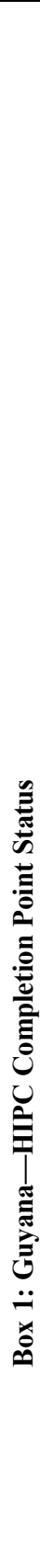 & 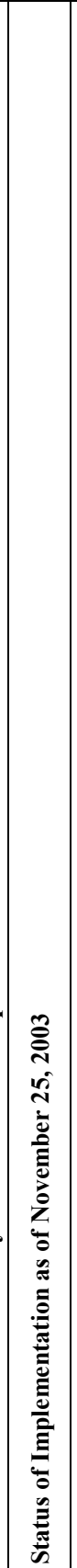 & 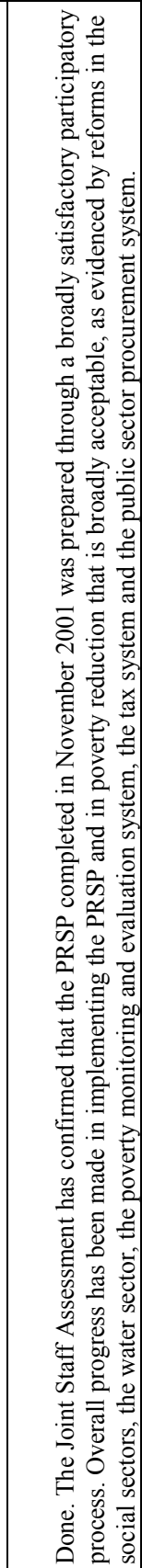 & 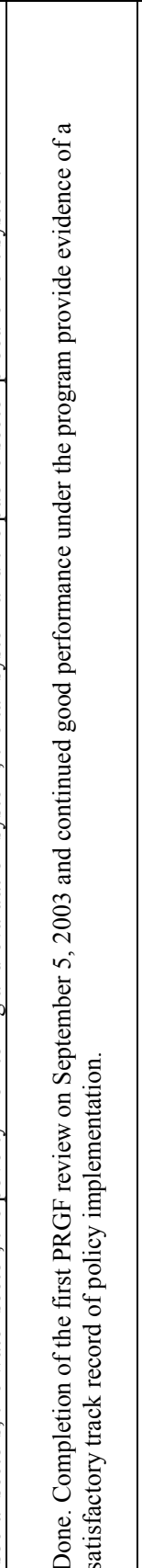 & 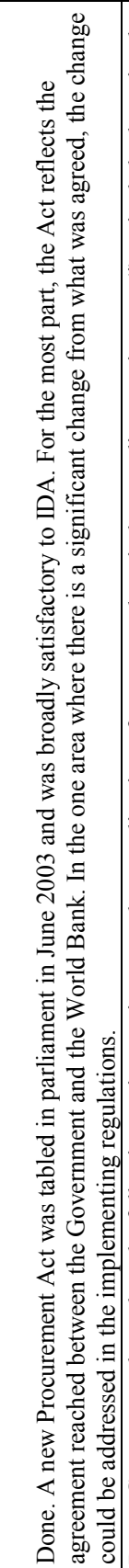 & 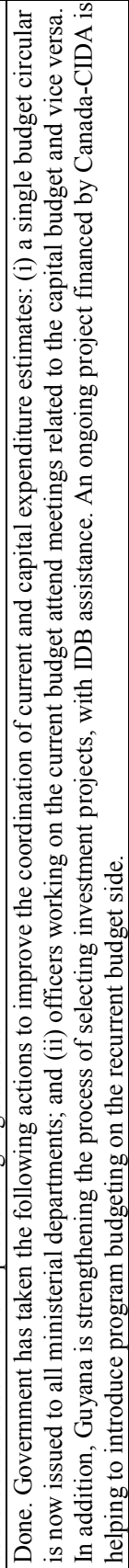 & 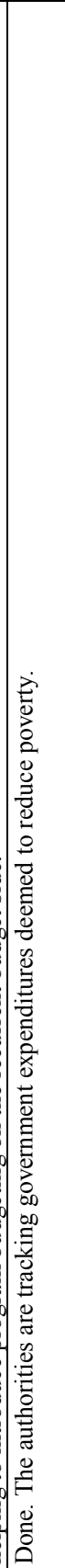 & & 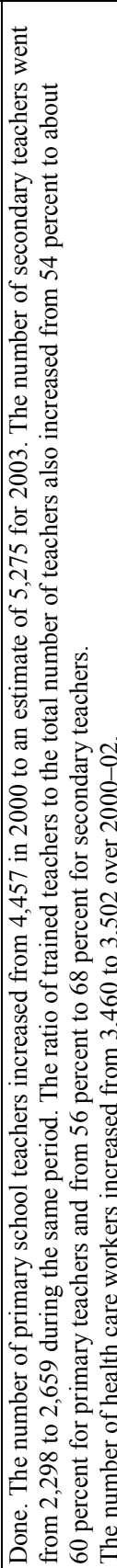 & 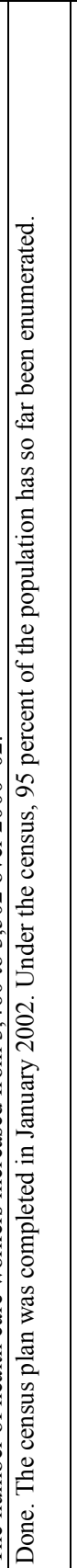 & & 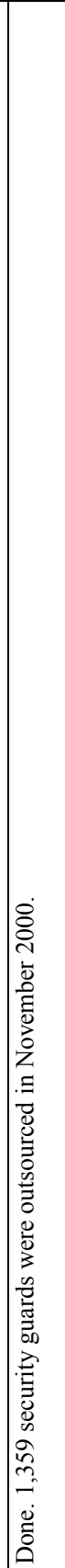 & $\mid \stackrel{\mathscr{0}}{0}$ & 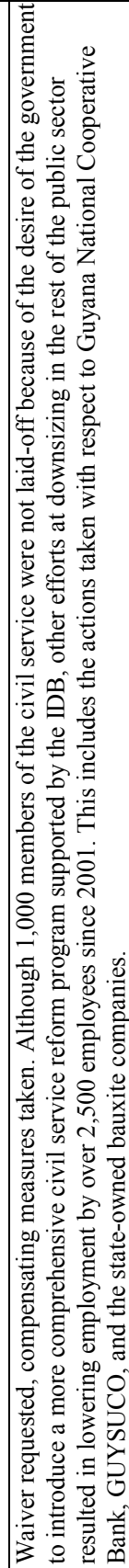 & 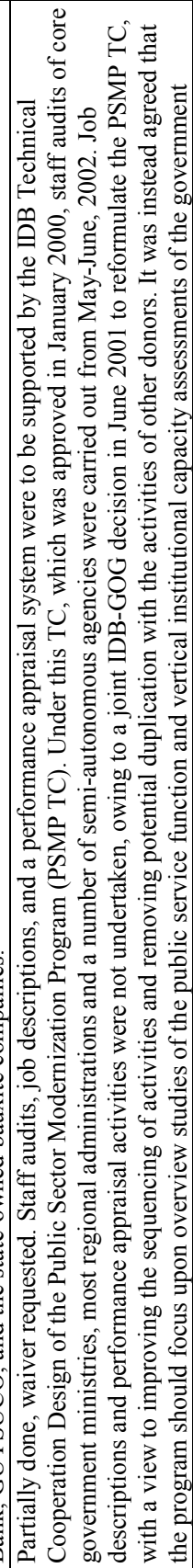 \\
\hline & 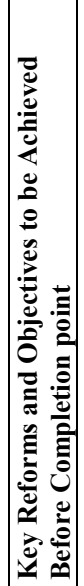 & 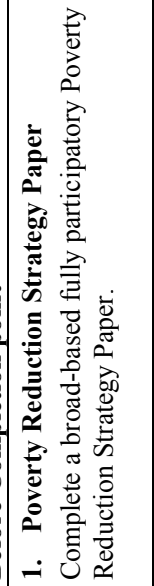 & 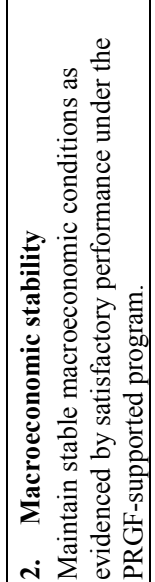 & 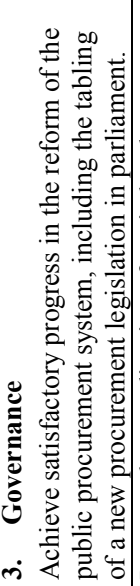 & 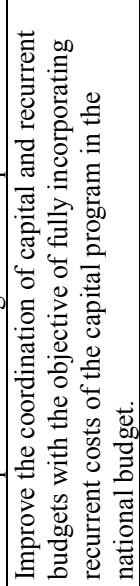 & 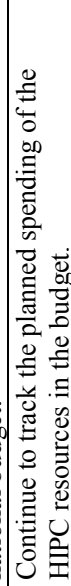 & 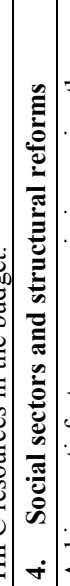 & 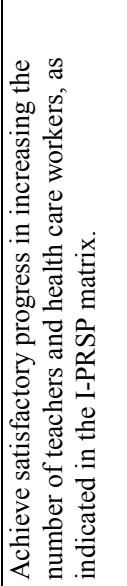 & 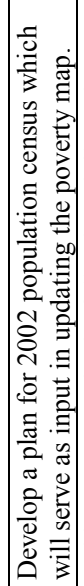 & 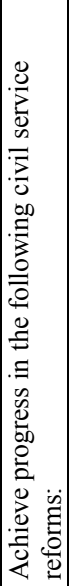 & 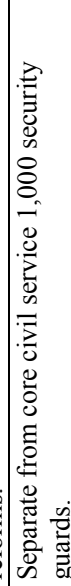 & 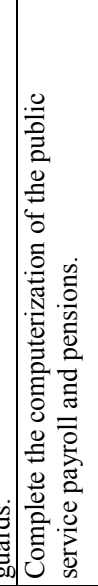 & 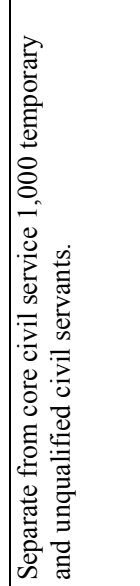 & 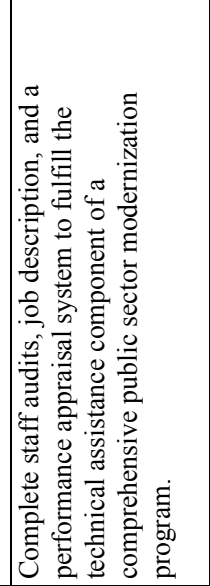 \\
\hline
\end{tabular}


$-6-$

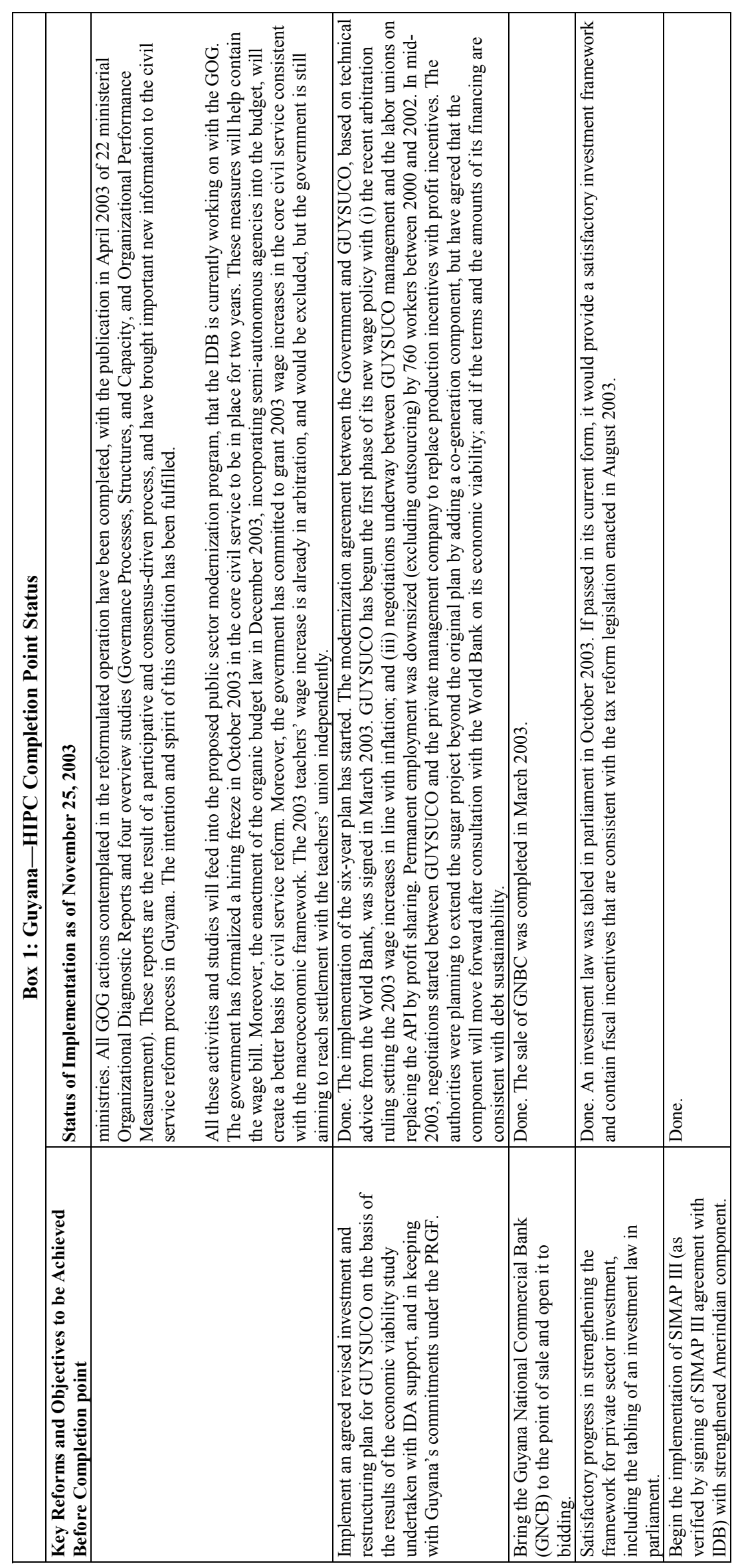


4. The debt stock estimate for Guyana as of end-1998 was revised upwards to US\$ 833.1 million in NPV terms, US\$5.9 million higher than the amount indicated at the decision point qualifying it for additional assistance (Table 2). The revisions come mostly from new information from non-Paris Club and commercial creditors, and new calculations.

\section{Assessment Of Requirements For Reaching The Completion Point}

5. Over the past few years Guyana has maintained macroeconomic stability (Tables 3-5) despite a difficult external, political, and security situation. While progress with reforms in 2001-02 was mixed with the first PRGF going off track, their implementation has resumed in 2003. The implementation of the PRSP has progressed and there is some improvement in poverty indicators. The PRGF-supported program is on track, with the first review completed in September 2003 and good progress in policy implementation thereafter. Moreover, structural reforms have gained momentum, as indicated by satisfactory performance in meeting most of the pending completion point triggers and in implementing reforms envisaged under the PRGF and the Poverty Reduction Support Credit (PRSC).

\section{A. Implementation of the Poverty Reduction Strategy}

6. The PRSP faces a formidable challenge in improving Guyana's social indicators. These continue to lag those of the region despite improvement since the launch of the Economic Reform Program in the late 1980s. ${ }^{5}$ Many basic indicators remain significantly below those of most other countries in Latin America and the Caribbean (see Table 1). In 2001, life expectancy at birth was 63 years in Guyana compared with 70 years in Latin America and the Caribbean, and the percentage of malnourished children under 5 was 12 percent in Guyana compared with 9 percent in the region. Moreover, the recent weak growth may have adversely affected some indicators.

7. The broad policy reform agenda outlined in the PRSP is geared toward enhancing productivity and competitiveness to promote sustainable growth and poverty reduction, and improving the delivery of essential social services. The strategic pillars of the PRSP are: (i) broad-based, jobs-generating growth; (ii) stronger institutions and better governance; (iii) investment in human capital, with emphasis on basic education and health; (iv) investment in physical capital; (v) improved safety nets; (vi) special intervention programs to address regional pockets of poverty; and (vii) environmental protection. The PRSP focuses on improving governance and public sector accountability, and on enlarging access and improving equity in the delivery of education and health services through increased spending on primary health care, primary and secondary education, water and sanitation, and housing.

\footnotetext{
${ }^{5}$ The PRSP was finalized in November 2001 and builds on the National Development Strategy (1996) and the Interim-PRSP (2000), both of which were developed in wide consultation with civil society. The PRSP reflects the results of an extensive participation and consultation process and was discussed at the IMF and World Bank Boards in September 2002.
} 
Table 1. Selected Social Indicators: Guyana and Comparators, 2001

\begin{tabular}{lrrr}
\hline & Guyana & $\begin{array}{r}\text { Latin America } \\
\text { and the Caribbean }\end{array}$ & $\begin{array}{r}\text { Lower-Middle } \\
\text { Income Countries }\end{array}$ \\
\hline Poverty incidence (percent below poverty line, 1999/2000) 1/ & 35 & $11-26$ & $\ldots$ \\
Urban population (percent of total population) & 38 & 75 & 42 \\
Life expectancy at birth (years) & 63 & 54 & 69 \\
Infant mortality (per 1,000 live births) & 12 & 30 & 32 \\
Child malnutrition (percent of children under 5) & 4 & 9 & 11 \\
Prevalence of HIV/AIDS (female, percent ages 15-24) & 1 & n.a. & 12 \\
Illiteracy (percent of population 15+) & & 12 & 15 \\
\hline
\end{tabular}

Source: World Bank, Social Indicators Data Base, 2003.

1/ For Guyana, the poverty incidence of 35 percent is for 1999 based on a national poverty line of US\$1.40 a day. (or 19.1 percent with a poverty line of US $\$ 1.08$ a day). For the LAC region it ranges between 10.8 percent and 26.3 percent for 2000 based on a poverty line of US\$1.08 and US\$2.15 a day, respectively.

8. Since the adoption of the PRSP, progress has been made in reaching several of its objectives, albeit with delays. In particular, advances have been made in achieving objectives (ii) through (v), with good progress in the water sector, the sugar sector, the government procurement system, and the monitoring and evaluation of programs and projects (including the tracking of poverty reducing spending). However, economic growth and government revenues in 2002-03 have been substantially lower than anticipated in the PRSP, as discussed below. This weak growth has adversely impacted the authorities' ability to reach objectives (i), (vi), and (vii). They have committed to completing a PRSP update by end-2003 to reflect the more difficult environment. It is difficult to assess whether durable changes are being made to the poverty situation because data on many of the PRSP targets are not yet available. However, poverty spending in terms of GDP has increased (Figure 1), the PRSP target for infant mortality reduction in 2001 was exceeded, and the number of health workers and teachers has also risen in recent years.

9. Based on the current progress, the PRSP poverty-related targets appear to fall short of achievement of the Millennium Development Goals as stated in the Joint IDAIMF Staff Assessment (2002). Of critical concerns are the targets related to poverty incidence, infant mortality and maternal mortality. The PRSP progress report, which is under preparation, is expected to discuss in more details the progress made so far in achieving the MDGs and the actions that need to be taken by the government to correct for the shortcomings.

\section{B. Broad-based Growth and Maintenance of Macroeconomic Stability}

10. A key growth challenge for the PRSP is to broaden the economic base and improve the competitiveness of traditional sectors. This would allow the country to increase its growth potential and better withstand external shocks. The difficulties facing the traditional sectors and the absence of major new mining ventures imply a need for new 
sources of growth and employment. Possibilities are agro-processing, forestry and ecotourism, given Guyana's extensive tropical rainforest coverage.

\section{Programs supported by the PRGF since the decision point discussion in late 2000} have aimed at reversing the stagnation in output since 1998. However, growth has remained sluggish in 2000-03 at an average of 1 percent, because of competitivenessreducing wage increases and delayed structural reforms in a difficult political and security situation. Slippages in fiscal and structural policies led the 2001 PRGF-supported program off-track. A new three-year program was adopted in September 2002. It focuses on boosting export competitiveness with efficiency-enhancing structural reforms especially in the state enterprises, improving the framework for private investment, reining in increased wage costs and reinforcing the public finances while increasing poverty-reducing expenditure. These measures have been complemented by reforms under the PRSC which was adopted in December 2002.

\section{Despite weaker activity than envisaged in 2002, macroeconomic performance} under the new PRGF program, has been broadly satisfactory. The economy stagnated despite increasing sugar output, reflecting slow implementation of structural policies, a weak external economic environment, and a deteriorating domestic security situation. Inflation at 6 percent was slightly above projections, reflecting mainly utility price increases. The gross official international reserve position at end-2002 was strong, covering 4.2 months of 2003 imports, 150 percent of base money and over 700 percent of short-term external public debt. The external current account deficit fell below 15 percent of GDP (20.2 percent of GDP in the program), owing to weak import growth in the context of a stagnant domestic economy and delays in implementing capital projects.

13. Some end-2002 performance criterion were missed. The 2002 nonfinancial public sector (NFPS) deficit was significantly below program target (5.9 percent of GDP compared to 7.6 percent), as lower domestic interest costs and capital expenditures more than offset weak performance in the public enterprises. However the performance criteria on the Bank of Guyana's net domestic and net foreign assets were missed, as delays in amending procurement legislation (see below) held up programmed IDA Credit disbursements.

\section{The first review of the PRGF-supported program was completed in September}

2003. This followed a period of six months of successful policy implementation between January 1, 2003 and end-June 2003. Over this period the budget target set by Fund staff was largely met, inflation remained close to program objectives, and the exchange rate was fairly stable. The revised 2003 program was based on a NFPS deficit of about 9 percent of GDP that accommodates large outlays for sugar sector restructuring and for certain delays in structural reforms, ${ }^{6}$ and takes into account the adverse impact of weak growth on revenues. Although the revised deficit target is somewhat higher by 0.4 percent of GDP than in the original program, it is consistent with macroeconomic stability as it comes at a time of weak private demand. To achieve the fiscal objective, the authorities have taken steps to improve

\footnotetext{
${ }^{6}$ The underlying deficit for 2003, excluding these outlays, is set at 6.4 percent of GDP.
} 
the tax system and its administration, to restructure public enterprises, and to cut budget outlays that do not affect poverty.

15. The program continues to be implemented successfully. All end-September 2003 indicative targets were met, except for the net foreign assets (NFA) target of the Bank of Guyana. It was missed by a small amount due to a delay in export receipts. Twelve-month inflation was at 6.2 percent in September and continues to be close to the programmed 6 percent, and gross international reserves of US\$262 million at end-September covered four months of projected 2004 imports. The stabilization of the political situation in May has helped advance the structural reforms supported by the program, including a comprehensive tax reform (see para. 29) and further restructuring of public enterprises. ${ }^{7}$ The authorities have implemented one end-December structural performance criterion on improving tax administration ahead of schedule. Amendments to the Guyana Revenue Authority (GRA) Act to improve its human resource management were enacted in October instead of December. Work is well underway to meet the other end-December structural performance criteria.

16. On present trends, the end-December quantitative targets are likely to be met although there are risks regarding the ceiling on wages in the public sector since 2003 wage negotiations are ongoing. Discussion on 2003 wages for teachers has already ended up in arbitration, but the authorities are still trying to reach settlement with the teachers' union independently. Moreover, they have committed to grant wage increases in the core civil service consistent with the macroeconomic framework prior to Board consideration of the completion point. The program assumes a wage increase of 6 percent, in line with projected inflation. They have also committed to enacting an organic budget law prior to Board consideration.

\section{Stronger Institutions and Better Governance}

\section{Actions have been taken to improve the government procurement process and} increase the productivity of public investment. The procurement process has suffered from understaffing, low thresholds calling for government review of contracts, conflicts of interest and a lack of centralized oversight that has led to delays and misuse of funds. A new Procurement Act (completion point trigger), passed by the National Assembly in May 2002, addressed some of these issues. However, it allowed continued cabinet intervention in the approval process, overlooked the role of the Public Procurement Commission (PPC) in parliament, centralized the decision-making process, and was not based on public consultation. To address these issues, the government decided to repeal the existing Procurement Act and, in consultation with IDA, presented a revised draft law to parliament which was ratified on July 24, 2003.

\section{Recognizing the importance of private sector development to growth and} poverty reduction, the government has recently taken steps to improve the investment

\footnotetext{
${ }^{7}$ The opposition came back to parliament in May 2003 after nearly 14 months of absence due to disagreement with the ruling party on a complex of constitutional and political issues.
} 
climate through institutional and legal reforms (completion point trigger). On the institutional side, the investment promotion agency (Go-Invest) has been revived by the appointment of a new chief executive officer. On the legal side, the government enacted the procurement law in July 2003 and in August, passed two other important acts to reform the tax system (see para. 27). In October 2003, it submitted new legislation to parliament to improve the investment climate, including for small enterprises. The legislation establishes basic guarantees and rights for investors (e.g., against expropriation) and makes incentives more transparent.

\section{Investment in Human and Physical Capital}

19. The provision of water and sanitation services is being rationalized, which helps set the stage for expanding service delivery and coverage. In 2002, the two state-owned water companies were merged into a single company (Guyana Water Inc., GWI) and legislation was enacted establishing quality standards and a mechanism to manage water resources. The initiation of private management of GWI in January 2003 is expected to promote sectoral restructuring, with capital outlays for service expansion and water quality improvements partly funded through better cost recovery.

20. In the health and education sectors, the government has recently introduced several initiatives (completion point trigger). As indicated earlier, the paucity of data makes an evaluation of improvements in these sectors difficult. However, the number of health workers has increased by about 5 percent per annum over the 1999-02 period and infant mortality rates are down. In terms of policies, the recently approved National Health Plan has prioritized the consolidation of facilities, management and service delivery, and training programs to increase and retain skilled staff. Particular attention will be given to expanding service delivery in hinterland areas. Some underutilized facilities will be closed, others consolidated, and some hospitals converted to outpatient polyclinics. Adequate upgrading, maintenance and staffing of facilities will be crucial. Efforts to fight HIV/AIDS have been intensified, with the elaboration of a HIV/AIDS National Strategic Plan encompassing education, counseling, and the adoption of treatment guidelines and access to antiretroviral drug therapy. Moreover, a major health sector program is being prepared with IDB support to strengthen the institutional capacity of the system, and to foster human resource development and improvements in health service delivery. In the education sector, priorities include teacher training and retention, facilities management and availability of books and school supplies, and accessibility and affordability of school attendance for families. Although these efforts have sustained primary and secondary school enrollment rates at high levels, chronic absenteeism and poorly qualified teachers have contributed to poor results. Indeed, national scores on the Caribbean Examinations Council remain substantially below the Caribbean average, despite considerable improvement in recent years.

21. The retention of qualified personnel is a chronic problem, both at the national level and in rural regions, especially in the education and health areas. Every year a large number of Guyanese emigrate contributing to high vacancy rates and continuing reliance on unqualified workers. Indeed, in 2000 up to 40 percent of positions in the ministry of health were vacant and 43 percent of secondary teachers were classified as untrained. Since then, the 
share of unqualified secondary teachers has fallen by 12 percentage points. To address the problem of staff retention, the IDB-funded Basic Education Access and Management Support (BEAMS) project is providing in-service training opportunities and developing teacher accommodations in remote areas. Moreover, a recently approved education project (Education For All-Fast Track Initiative) will devote nearly US\$5 million to training teachers in the hinterland areas using a distance-learning approach, constructing houses for teachers and providing a hardship allowance.

\section{Available information suggests that key social performance indicators under the} enhanced HIPC Initiative improved in 2000-02 (see Table 2 below). The number of teachers (primary and secondary) increased by 5-6 percent per annum (completion point trigger), the ratio of trained teachers by 5-10 percentage points, and the student drop-out rates declined by 3 percent. With respect to the health sector, the number of workers has gradually increased during 2000-02. The European Union (EU) is restructuring its aid program with Guyana, and, beginning in 2004, its direct budget support program will be linked to Guyana's ability to achieve a variety of social sector benchmarks, initially, in the health and housing sectors. It is therefore vital for the government to develop these and other indicators presented in its PRSP, and organize a transparent mechanism for tracking and reporting performance. The Policy Coordination and Program Management Unit, set up in 2001 at the Presidency, should take the lead in this context.

Table 2. Guyana: Selected Education and Health Indicators, 1999-2003

(Number of workers, except where noted)

\begin{tabular}{|c|c|c|c|c|c|}
\hline & 1999 & 2000 & 2001 & 2002 & $\begin{array}{r}\text { Est. } \\
2003\end{array}$ \\
\hline $\begin{array}{l}\text { Primary teachers } \\
\text { Of which }\end{array}$ & 3951 & 4457 & 4808 & 5048 & 5275 \\
\hline Trained (percent) & 50 & 54 & 57 & 60 & 59 \\
\hline $\begin{array}{l}\text { Secondary teachers } \\
\text { Of which }\end{array}$ & 3371 & 2298 & 2412 & 2532 & 2659 \\
\hline Trained (percent) & 58 & 56 & 64 & 69 & 68 \\
\hline Total of newly trained teachers & 320 & 509 & 576 & 472 & n.a. \\
\hline Student drop outs (primary) & 2209 & 2100 & 2005 & 1992 & n.a. \\
\hline Student drop outs (secondary) & 2500 & 2326 & 2275 & 2198 & n.a. \\
\hline Health care workers & 3057 & 3460 & 3475 & 3502 & n.a. \\
\hline
\end{tabular}

Source: Government of Guyana. 


\section{E. Improved Tracking of Poverty and Regional Poverty Programs}

23. The authorities have been tracking pro-poor growth spending fairly successfully (completion point trigger). As shown in Figure 1, the government's pro-poor growth spending - i.e., spending on education, health, housing and water, and other poverty alleviation programs - has substantially increased since 1997, both in real and relative terms. It grew by an annual average rate of 5.9 percent in real terms between 1997 and 2002, faster than GDP growth (0.7 percent) and total spending (3.2 percent). As a share of GDP, it increased from around 15 percent in 1997 to 20 percent in 2002, although it has stabilized at this level since 2000. Spending on both education and health increased sharply in relation to GDP during the period under review, with the share of education more than doubling and the share of health increasing by 50 percent. In both sectors, the increase is largely accounted for by spending on books, supplies and wages.

24. However, advances in intervention programs to address regional pockets of poverty have been limited, owing to the lack of information on the extent of poverty. This drawback is being rectified through the development of biennial household and expenditure surveys, the first of which is expected to be processed by end-2004, and a population census in 2002 (completion point trigger).

Figure 1. Guyana: Pro-Poor Growth Spending
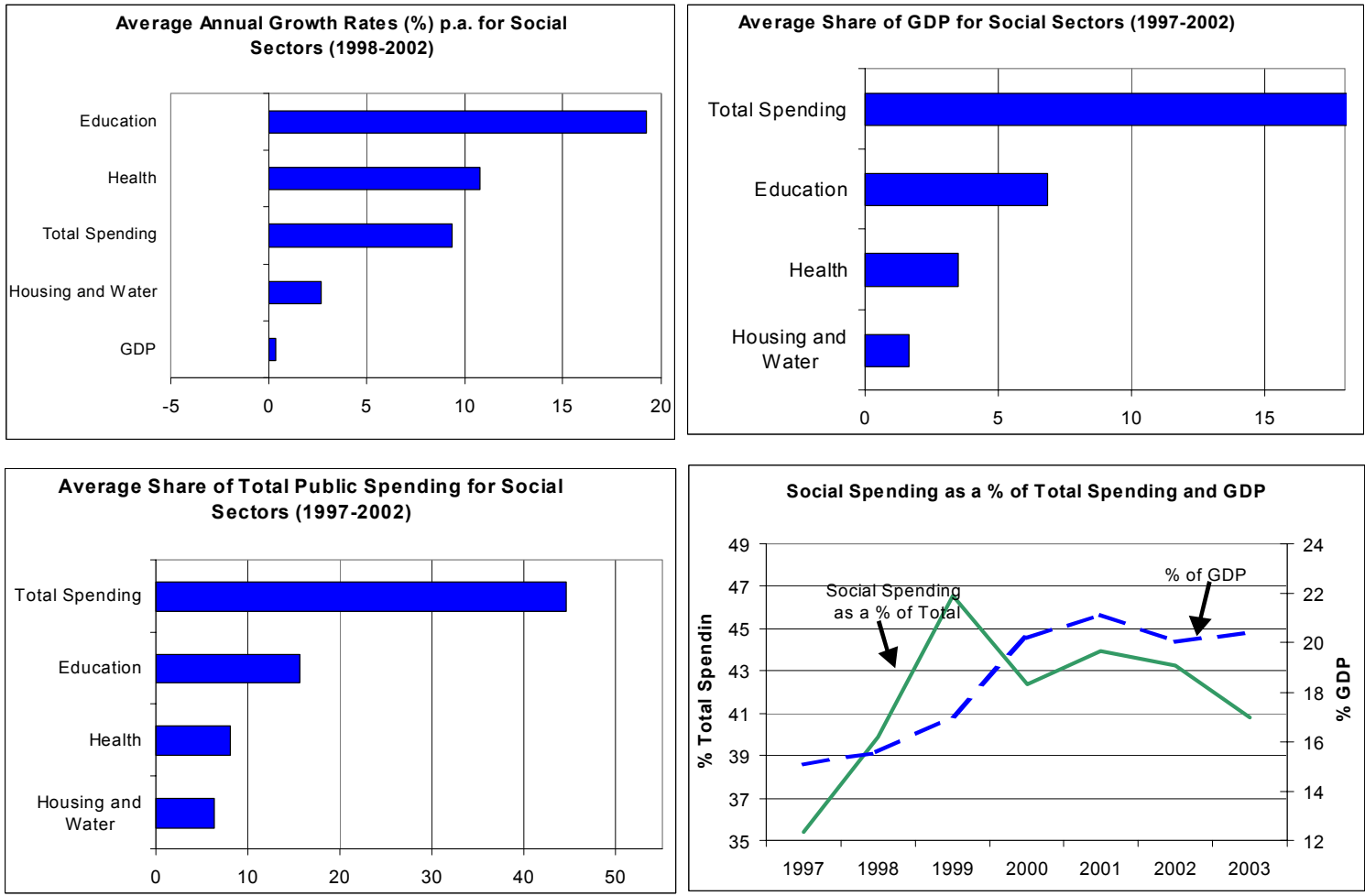

Source: Government of Guyana. 


\section{F. Public Enterprises, Taxation, and Civil Service Reform}

25. Since the decision point, Guyana has made important progress in implementing other structural reforms not highlighted in the PRSP, but critical for poverty reduction. Several, including social sector and civil service reforms, and restructuring of public enterprises, are among the triggers for reaching the enhanced HIPC initiative completion point.

26. Guyana's state-owned sugar company (GUYSUCO) is being restructured (completion point trigger). The aim is to reduce the economy's vulnerability to a decline in the sugar export price from the expected liberalization of the world sugar market in 2006. Since 1997, production has risen by $2 \frac{1}{2}$ percent per annum on average while U.S. dollar unit costs have declined by 6 percent. With technical support from IDA, GUYSUCO has started implementing a policy framework to restructure the sugar sector. The framework aims at lowering production costs to US\$0.13 cents per pound by 2006 , the current estimate of the world sugar price following liberalization. This is to be achieved through the construction of a more efficient processing plant and by linking worker and management remuneration to company profitability rather than production. At the same time, productivity gains and cost savings would be achieved through downsizing. Some downsizing has already taken place: GUYSUCO reduced its permanent labor force by some 760 employees (over 4 percent of total) between 2000 and 2002, and a further reduction of 700 is expected by end-2003.

27. The state-owned bauxite companies are being restructured to promote fiscal and external viability. This would eliminate existing budgetary transfer payments and make more resources available for poverty-reducing programs. In mid-2002, two loss-making companies (BERMINE and AROIAMA) were restructured and merged into a new cashneutral company (i.e., requiring no subsidies from the central government). Also, since June 2002, a large, loss-making company (LINMINE) is being restructured, with the upgrading of mining and transportation operations, an improvement in the reliability of electrical power, the privatization of its management, and the reduction of its work force from around 1,250 in 2002 to 250 at end-September 2003.

28. A number of measures have been taken to strengthen the financial sector. With support from the international financial institutions and CARTAC, the state-owned commercial bank (GNCB) was successfully sold to a domestic commercial bank in early 2003 (completion point trigger) and a satisfactory plan is being implemented to recover its nonperforming loans. The plan involves recovering the top 100 nonperforming loans, 50 of which have already been assessed. Over the coming year, the authorities intend to overhaul the financial institutions act with the objective of strengthening the ability of the Bank of Guyana to deal proactively with problem institutions and ensure consistency vis-à-vis international best practice.

29. To enhance government revenue collection while improving external competitiveness, Guyana has begun implementing a comprehensive reform of the tax system and its administration, albeit with delays (Box 2). The reform broadens the tax base, improves the overall efficiency of the system, and reduces the scope for discretion. It also envisages the introduction of a value added tax (VAT) in April 2006 after the next 
national elections, which is considerably later than the recommendation of the Fund's technical assistance team. To help implement the reform, the authorities have appointed highly qualified and experienced professionals as Commissioner General and Deputy Commissioner General in the GRA, and, as discussed above, amended the GRA Act in October 2003 ahead of schedule to grant it full autonomy in the management of its human resources.

\section{Civil service reform is being addressed, albeit later than envisaged at the time of}

the decision point. In 2000, the government outsourced over 1,300 security guards (compared with a target of 1,000), but it has been unable to downsize the core civil service by a further 1,000 employees (as originally envisaged by the completion point) given the existing high political and ethnic tensions and the potential for serious social and ethnic unrest. As a result the authorities are requesting a waiver of this condition. In 2002, the government payroll and pensions database was computerized (completion point trigger); a payroll audit was carried out; vacant positions were abolished and rules for establishing new positions were established. However, the preparation of job descriptions and a performance appraisal system (completion point trigger), were postponed and only institutional and organizational capacity assessments across ministries were undertaken. These assessments were completed in May 2003. The authorities are requesting a waiver of this condition as well.

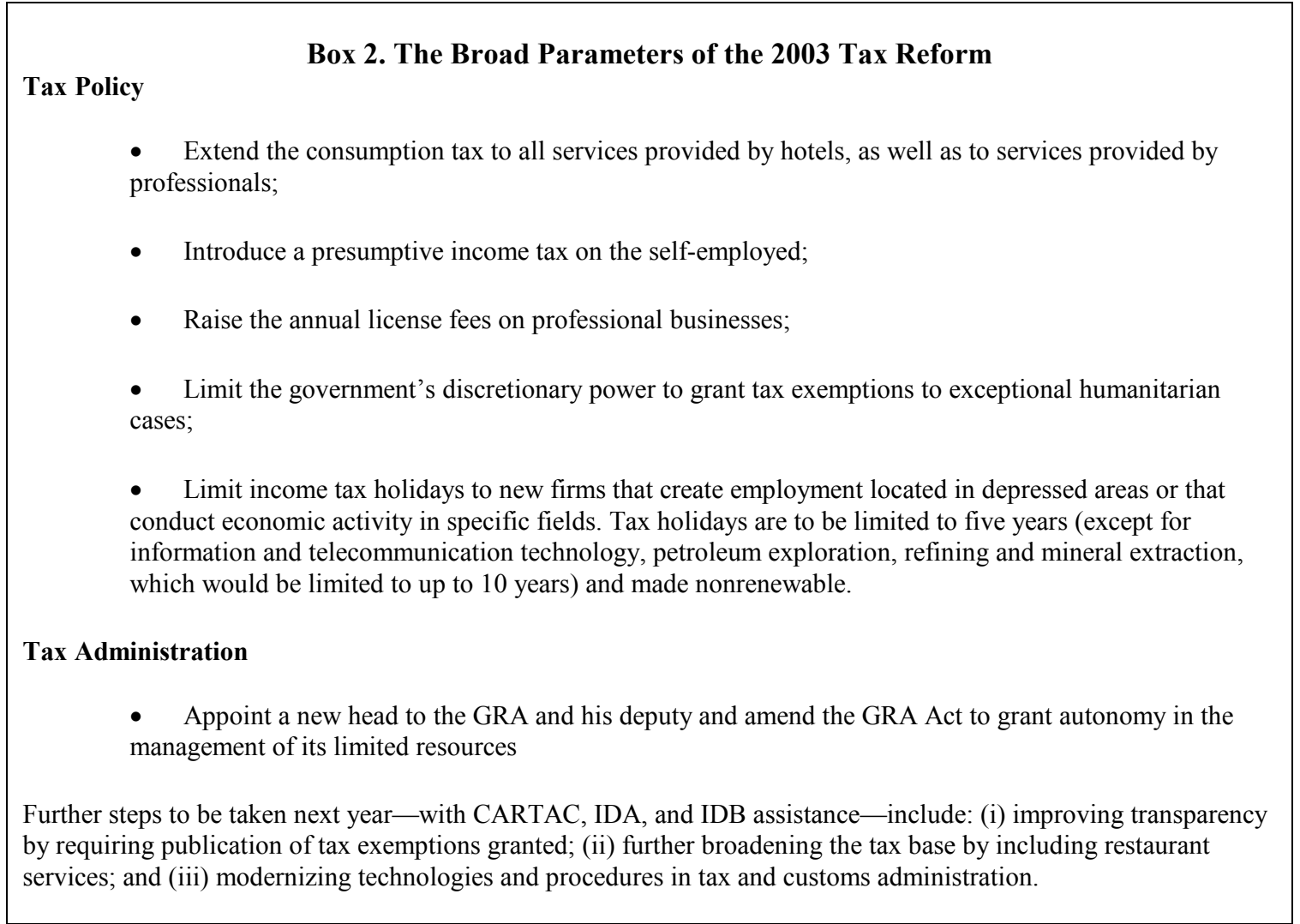


31. The government has taken compensatory measures to support the waiver requests. The downsizing outside the civil service in the public sector (over 2,500 people in the mining, sugar, and banking sectors) has more than compensated for the failure to reduce the civil service per se. Moreover, although the job descriptions and performance appraisal system have not been carried out, the civil service reform has been advanced by the preparation of a comprehensive public sector modernization program by the IDB. This has included a broad diagnostic of the problems of the sector and a proposal for reform with consultant studies, which are now under discussion with stakeholders, but the policy will not be effective until 2005. As a stop-gap measure, the government also reaffirmed a hiring freeze in the core civil service with a new government circular, which will remain in place until the IDB-supported program is operational. It has also committed to grant 2003 wage increases in the core civil service consistent with the macroeconomic framework prior to the Board discussion of the completion point. These actions will help to contain future increases in the wage bill and stem its continuous rise in recent years (from about 8 percent of GDP in 1998 to a projected 12 percent of GDP in 2003). The government has also committed to enact an organic budget law incorporating semi-autonomous agencies prior to Board consideration of the completion point. This would create a more solid basis for reform in the sector, and complement the coordination of current and capital expenditure estimates (completion point trigger) which has already been accomplished. Under these policies the wage bill is projected to decline gradually over the long-run. The staffs consider that these compensatory measures signal satisfactory progress toward meeting the conditions on civil service reform set out in the decision point document.

\section{DELIVERY OF DEbT RELIEF AND MEDIUM-Term SuSTAINABILITY}

\section{In the process of updating the debt sustainability analysis (DSA) for the completion point, IDA and IMF staffs and the authorities solicited new creditor} statements. They revised the estimate for the end-1998 NPV of debt after original HIPC assistance to US\$833.1 million in NPV terms in the decision point document. The structure of the debt was as follows: 61 percent is held by multilateral institutions, 28 percent by Paris Club bilateral creditors, and 11 percent by non-Paris Club and commercial creditors (Tables 6-11). The revisions come mostly from non-Paris Club and commercial creditors' new information and calculation revisions. ${ }^{8}$ The original data on debts to multilateral creditors were confirmed. This requires an upward revision of assistance, ${ }^{9}$ and enhanced HIPC assistance required thus increases from US\$328.6 million in the decision point document to US\$334.5 million in 1998 NPV terms. The additional assistance of US\$5.9 million in NPV terms is equivalent to 3 percent of government revenue in 1998. The

\footnotetext{
${ }^{8}$ Debts to Cuba and Bulgaria were not included in the decision point document because they were only recently uncovered when the state bank was privatized. Moreover, some commercial loans were reclassified, requiring revised calculations (India, United Arab Emirates and the United Kingdom). Revised calculations were also done for Democratic People's Republic of Korea (DPRK) and External Payment Deposit Scheme (EPDS)

9 "Information Reporting in the context of HIPC Initiative Assistance" approved by the Boards of the IMF(www.imf.org) and IDA(IDA/SecM2002-0131), March 4, 2002.
} 
common reduction factor that would be applied by all creditors to their end-1998 NPV debt after full delivery of the original HIPC assistance would become 40.2 percent.

\section{A. Status of Creditor Participation and Projected Profile of Relief}

\section{Multilateral creditors}

33. Under the original HIPC Initiative, multilateral creditors were to provide 64 percent of total assistance equivalent to US\$165 million in end-1998 NPV terms (Tables 12-17). IDA has contributed US\$27.1 million in 1998 NPV terms through the purchase and cancellation by the HIPC Trust Fund of 10 IDA credits, including all remaining U.S. dollar credits, worth US\$54 million. The IMF gave a grant from the PRGF-HIPC Trust through a deposit on an escrow account being used to meet Guyana's debt service to the IMF, the IDB has contributed via a combination of write-offs of selected concessional loans, and partial payment of interest on other selected loans. The CARICOM Multilateral Clearing Facility (CMCF) has given relief via a loan cancellation operation, while the OPEC Fund has given debt relief through a concessional arrears clearance and a restructuring of an existing loan. The Caribbean Development Bank (CDB) has provided relief through the use of internal resources to cover debt service coming due on CDB loans. The International Fund for Agricultural Development (IFAD) gave relief via the IFAD-administered facility, covering 100 percent of debt service until full relief in NPV terms is delivered. Finally, the EU and European Investment Bank (EIB) contributed via refinancing on grant terms.

34. Debt relief from multilateral creditors under the enhanced HIPC Initiative amounts to US\$202.3 million in NPV terms at end-1998 after an upward revision of US\$2.5 million in $1998 \mathrm{NPV}$ terms. IDB, IDA, the IMF, CDB, and the EU have granted interim relief. Other creditors, such as the OPEC Fund and IFAD, have committed themselves to providing the debt relief required under the Enhanced Initiative as soon as Guyana reaches its completion point. However, a portion of multilateral assistance calculated at decision point has not yet been secured, as the CMCF has indicated it has difficulty in participating fully.

The details of debt relief by multilateral creditors are as follows:

- Debt relief from the largest creditor, IDB, now amounts to US\$65.1 million or an additional US\$0.8 million in NPV terms. Since 2002 the IDB has provided interim assistance amounting to US\$16.4 million in nominal terms. The enhanced HIPC assistance would come from a reduction of Funds for Special Operations (FSO) loans until 2008, and via selective cancellation of principal payments on FSO loans thereafter.

- Debt relief from the IMF now amounts to US\$40 million in NPV terms including an additional US\$0.5 million in NPV terms due to the revision. As of December 2003 the interim assistance provided since 2000 amounts to SDR15.4 million in nominal terms. The enhanced HIPC assistance is being delivered via debt-service reduction grants from the PRGF-HIPC Trust until 2008. 
- Total debt relief from the IDA amounts to US\$41.2 million in NPV terms including US\$0.5 million additional assistance in NPV terms due to the revision. The assistance is to be delivered by IDA through a debt service reduction from December 2000 to March 2021. Interim assistance over the period December 2000 and 2003 amounted to US\$6.5 million in nominal terms corresponding to a debt service reduction of 58.6 percent. The additional enhanced HIPC Initiative assistance from the IDA will be done by extending debt service reduction until March 2021 on IDA credits outstanding and disbursed as of endDecember 1998. This includes an additional assistance of US\$1.4 million in nominal terms.

- Debt relief from the CMCF amounts to US\$29.2 million in NPV terms incorporating an additional US\$0.4 million in NPV terms due to the revision. CMCF, representing 9 percent of enhanced HIPC assistance, will have difficulty in participating fully in the enhanced HIPC as one of its members faces financial constraints. Staff will continue to search for modalities that might resolve the issues and allow CMCF to deliver its full enhanced HIPC relief to Guyana.

- $\quad$ The enhanced HIPC Initiative assistance from the CDB amounts to US\$9.9 million in NPV terms including an additional US\$0.3 million due to the revision. The CDB intends to contribute US\$5.5 million in NPV terms out of the accumulated net income of the Special Development Fund. Donors represented on the Board of the CDB would provide the remainder of the assistance.

- Debt relief from the EU/EIB amounts to US\$10.6 million in NPV terms including an additional US\$0.1 million in NPV terms. It is being provided via debt service reduction using EU grants. Interim relief was given in 2002.

- Others. Debt relief from the OPEC Fund amounts to US\$5.4 million in NPV terms incorporating an additional US $\$ 0.1$ million. It will be given at the completion point through a combination of refinancing and the extension of a new "HIPC" loan which will be used to service existing loans. Debt relief from IFAD amounts to US\$1 million in NPV terms and changes only marginally with the revisions. It will be provided at the completion point through a 100 percent debt service reduction until the target NPV relief is reached.

\section{Bilateral and commercial creditors}

35. Following the revision of required HIPC assistance, bilateral creditors would need to provide US\$132.2 million in 1998 NPV terms (US\$94 million for the Paris Club) or an additional US\$3.4 million in NPV terms. In June 1999, at the conclusion of the stock of debt negotiations, the Paris Club indicated its willingness to reduce Guyana's debt further in the context of the enhanced HIPC Initiative. This commitment involved ten bilateral creditors, including Trinidad and Tobago. The relief provided under the original HIPC Initiative had consisted of a stock-of-debt operation with an 80 percent NPV reduction of eligible debt. The enhanced HIPC assistance would be provided through a stock-of-debt operation on Cologne terms at the completion point. A number of Paris Club creditors indicated that they would provide debt relief beyond that required under the terms of the enhanced HIPC Initiative, estimated to amount US\$15.1 million in NPV terms. 
36. Non-Paris Club bilateral and commercial creditors are expected to provide treatment comparable to that of the Paris Club creditors. Of these creditors, China, India, and Libya have indicated their intention to provide debt relief in the context of the enhanced HIPC Initiative. China has already started providing relief through the cancellation of some loans, and in March 2003 India indicated its intention to write off all of Guyana's debt. In 1999, Guyana concluded a buyback operation financed by the IDA Debt Reduction Facility with $\operatorname{EPDS}^{10}$ for 72.4 percent of its debt. Government bonds (formerly the debt of Guymine) with a face value of US\$27.5 million were bought at a discount by Citizen Bank in 2002 and became domestic debt not subject to debt relief. This amount is projected to be repaid in full in 2007 and the payment is currently included in the projections on the medium-term scenario. Earlier this year, Booker McConnell (commercial creditor, United Kingdom) decided to waive its appeal to the International Court for the Settlement of Investment Disputes for repayment of a loan valued at over US\$19 million, although it has not officially written off the debt. Concerning the other official bilateral creditors, the Guyanese authorities are continuing their efforts to obtain full HIPC debt relief, in accordance with the principles of the HIPC Initiative.

37. Financing assurances regarding enhanced HIPC Initiative assistance for Guyana are sufficient for the completion point. Financial assurances obtained by creditors represent about 81 percent of the total original and enhanced HIPC assistance approved in November 2000 (this figure does not include CMCF debt relief, see above). The staffs are working with the authorities to facilitate the endorsement of the enhanced HIPC Initiative framework by the remaining creditors.

\section{B. Long-Term Macroeconomic Framework}

38. The authorities updated the medium-term macroeconomic framework to reflect lower growth. For the period 2003-07, the new framework differs substantially from that presented at the beginning of the PRGF program one year ago (Box 3 on macroeconomic assumptions). In particular, growth projections were halved to $1 \frac{1}{2}$ percent per annum over the next five years compared to the original program. The downward revision reflects the deteriorating crime and security situation since mid-2002, which has had an adverse impact on private investment, growth, and consumer imports resulting in a poor performance in many industries in the non-traded sectors in the first half of this year. Moreover, gold reserves in the largest gold mine in Guyana are projected to run out by end 2006, explaining the drop in output in 2005-06. Over the longer term, potential growth for the economy has also been revised downwards by $1 \frac{1}{2}$ percentage points a year to $2 \frac{3}{4}$ percent owing to the absence of major new gold discoveries and a cautious assumption about developments in new expanding industries such as agro-processing.

39. The capital account projection is based on the assumption that the current security climate will improve and that Guyana will be able to attract foreign private

${ }^{10}$ The External Payment Deposit Scheme was a payment deposit scheme where arrears to many small commercial creditors were deposited. 
capital and bolster domestic saving. Gross domestic saving is projected to rise to 10 percent in 2007 in response to an improvement in public savings, but this will be insufficient to finance total domestic investment at about 24 percent of GDP per year. Hence, Guyana will continue to require substantial external official assistance and foreign direct investment over the long term. Structural changes and continued strong investment are projected to generate labor productivity growth of $1 \frac{3}{4}$ percent over the long run.

\section{Box 3. Guyana: Macroeconomic Assumptions Underlying the Debt Sustainability Analysis}

- $\quad$ Economic growth. The economy is assumed to grow at an average annual rate of $1 \frac{1}{2}$ percent during 2003-07. Weak growth prospects are based on low private investment and structural problems. By 2007 , growth would rebound and move to a projected medium term rate of $23 / 4$ percent, largely driven by higher growth in tourism, services, sugar production and mining.

- Inflation is projected to stay in the low single digits (about 3 percent) during 2003-22 in the context of sound monetary and fiscal policies.

- Central government revenues are projected to increase from 31 percent of GDP in 2003 to 33 percent of GDP in 2007, owing to changes in the tax system and improvements in its administration. From 2007 onwards, revenues are projected to stay flat in relation to GDP.

- $\quad$ The current account deficit is projected to fall from a peak of 19 percent of GDP in 2004, associated with the large sugar investment, to below 9 percent of GDP in 2022. The volume of exports grows on average at $2 \frac{1}{2}$ percent in the long term and imports are projected to grow in line with real GDP.

- $\quad$ Public sector external borrowing declines from $5 \frac{1}{2}$ percent of GDP currently to $2 \frac{1}{2}$ percent in the long run. The borrowing is almost completely provided by multilaterals, with an average interest rate of about 1 percent and a grant element of 40 percent. Foreign direct investment is projected to average about 7 percent of GDP over the long run. ${ }^{1 /}$

- $\quad$ Foreign grants amount to about 4 percent of GDP in the short-run, dominated by disbursements from the European Union. These disbursements are conditional on appropriate macroeconomic policies. In the long run, grants are projected to decline to $1 \frac{1}{2}$ percent.

1/ This seems high by international standards, but reflects high replacement rates in Guyana and capital intensity of its investments.

40. The overall fiscal deficit (after grants) is projected to decline to about 2 percent in 2008, after peaking at about 10 percent of GDP in 2003-04. Central government revenue is projected to rise by about 2 percent of GDP over the next few years as a result of the broadening tax base and improved tax administration. Restructuring efforts in public enterprises also will contribute to stronger fiscal savings. Government current primary expenditure would increase slightly, owing to higher poverty reducing spending. Government investment, however, would increase significantly in 2004-05 on account of the GUYSUCO restructuring project, and then decline sharply after its completion.

\section{The external current account deficit is projected to rise over the medium term,} but to decline to single digits over the long term. The expected temporary rise is associated 
with GUYSUCO's large sugar investment project. The deficit is projected to peak at about 19 percent of GDP over the next two years, up 2 percent from this year on account of the large sugar capital investment. Subsequently, the deficit falls to about 9 percent of GDP. Export volume is projected to decline through 2006 as the largest gold mine in Guyana is closed. Subsequently, exports grow at about $2 \frac{1}{2}$ percent per annum, fuelled by the assumption that sugar exports grow at about the same rate, with Guyana gradually taking over the CARICOM sugar market.

\section{Updated Debt Sustainability Analysis}

42. Based on the framework above, debt indicators show that debt relief provided under the enhanced HIPC Initiative would reduce Guyana's public and publicly guaranteed external debt considerably. By end-2002, the NPV of outstanding debt had risen to about US\$880 million. After enhanced HIPC relief, this amount would be reduced to US\$466 million at end-2003 with new debt accrued since end-2002 accounting for an additional US\$33 million (see Table 9). Although the initial relief amount corresponded to a target debt-to-revenue ratio of 250 percent at end-1998, revenues have grown more slowly than anticipated in the decision point document. Central government revenues for 2003 are now 21 percent below the level projected in 1998. As a result, the estimate of the ratio of debt to revenues for 2003 is at 220 percent, compared to the projection of 218 percent for 2003 made at the time of the decision point. Moreover, the ratio is projected to rise over the next few years associated with the large investment at GUYSUCO. The ratio is expected to peak at 248 percent in 2007, and to remain below 250 percent throughout the end of the projection period.

43. In the medium term, the ratio of debt service to government revenue stabilizes. In the decision point document, debt service was projected to decline to about 13-14 percent of revenues two years after the initial completion point date, which was set for 2001. Similarly, the latest estimate indicates that the ratio will be about 14 percent in 2008 , five years after the revised completion point date. This increase is in line with the weak government revenues experienced over the last few years. Debt service remains high over the whole projection period.

\section{Sensitivity Analysis}

44. This section examines the implications for debt sustainability under more pessimistic assumptions than those included in the baseline scenario described above (Table 18). Three scenarios are examined and compared to the baseline case in terms of their impact on the ratio of debt to central government revenues (Figure 2). 
Figure 2. Guyana: Debt Sustainability Indicators, 2003-22

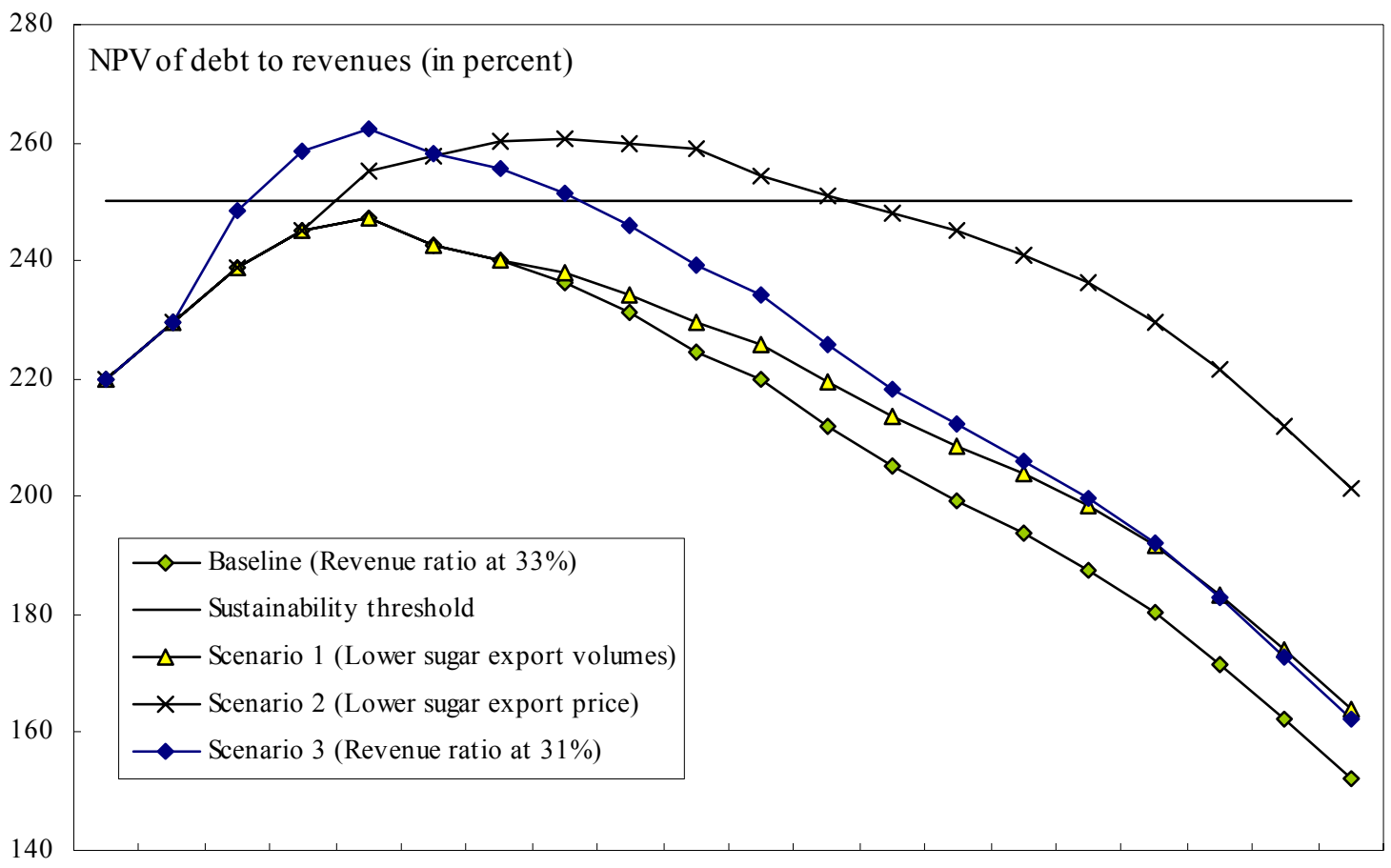

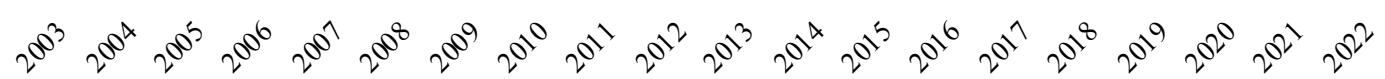

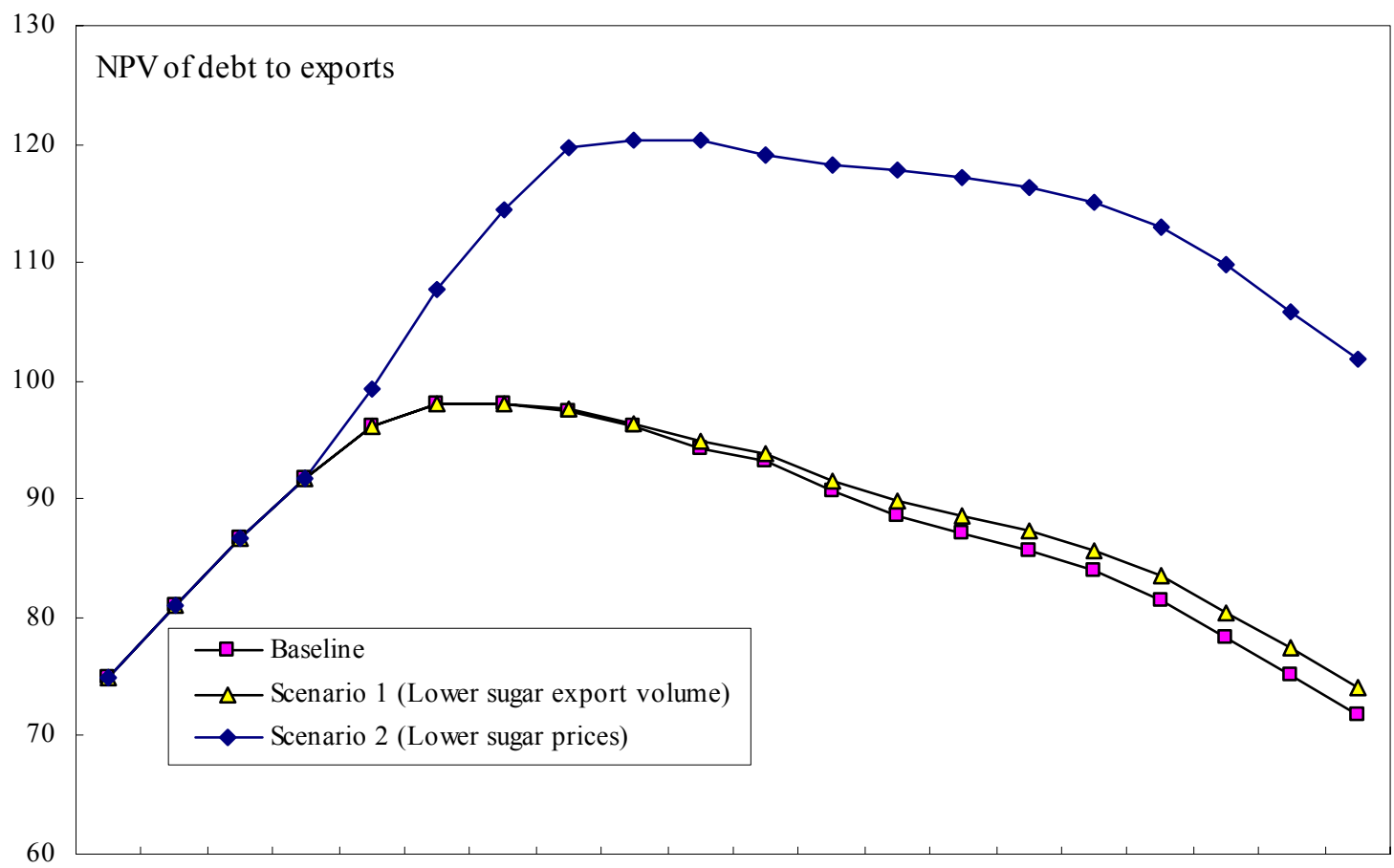

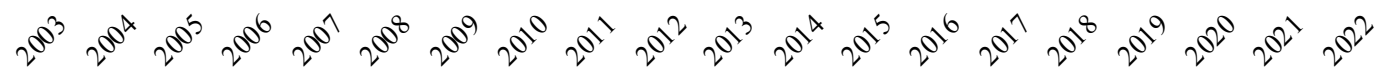

Source: Fund staff estimates. 
45. The first alternative scenario examines the likely impact of zero sugar export volume growth after 2008. In the baseline, sugar export volumes are projected to grow at an annual rate of about 2 percent from 2009 onwards. If Guyana is not able to penetrate the world market after this date because of increased competition, the growth of sugar exports after this date would be zero. Since sugar plays an important role in overall activity, such a decline in exports would lower aggregate growth by 0.4 percent in 2009 and by a permanent 0.2 percent over the longer term. Combining the effects of lower sugar exports and output growth yields a neutral effect on the balance of payments, with reduced exports compensated by reduced imports eliminating any need for additional external financing. However, central government revenues are clearly lower because of the weaker growth outcome, and this effect results in an increase in the debt-to-revenue ratio of about 10 percentage points to 164 percent in 2022. The NPV of debt to revenue would average 198 percent under the zero sugar export growth scenario, compared with 189 percent from 2012-22 under the baseline scenario.

46. The second alternative scenario examines the impact of a sharp decline in the world price of sugar in European markets. It depicts a 50 percent decline in the sugar price in 2007 following the end of the preferential price treatment offered to the poorest countries. The sugar price per pound is estimated to decline from 27 cents - the current price obtained by Guyana in the European market - to 13 cents per pound, which is a rough estimate of the world sugar price following liberalization. This terms of trade shock reduces exports by about 7 percent per annum creating a need for extra foreign financing to cover imports. External borrowing rises by about US $\$ 40$ million per annum over the 2008-22 period so that by the end of the period, the NPV of debt is up by over 35 percent. Since the direct contribution of the sugar company to central government revenues is minimal in the baseline, there is no change in revenues associated with the terms of trade shock. However, the higher NPV of debt results in an increase in the ratio relative to revenues of about 50 percentage points to 200 percent in 2022 , compared to the baseline ratio of debt to revenues at about 150 percent.

47. The third alternative scenario assumes that the government is unable to raise the ratio of central government revenues to GDP above 31 percent, compared to 33 percent in the baseline case. In this case, the debt to revenue ratio rises above 250 percent in 2006 , peaks at 257 percent in 2007 and then falls below 250 percent, but remains 10 percentage points above the baseline in 2022 .

48. The main risks to sustainability over the medium term are terms of trade shocks associated with liberalization in the sugar market, and the ability of the government to sustain the revenue base and control wage growth in the public sector. The sugar and tax reforms that are currently taking place and continued monitoring of the wage bill are crucial. None of the scenarios breach the sustainability target on the basis of exports because the export level is so high. In the baseline, the ratio of the NPV of debt to exports is about 70 percent in 2003, 80 percentage points lower than the sustainability threshold. As expected, the highest debt-to-export ratio is associated with the terms of trade shock in the sugar sector, but this scenario only gives rise to a maximum debt-export ratio of about 120 percent. 


\section{Conclusion}

49. The staffs of the IMF and IDA consider that Guyana's performance with respect to the conditions for reaching the completion point under the enhanced HIPC Initiative has been satisfactory. They therefore recommend that the Executive Directors approve the proposed revision to the enhanced HIPC Initiative debt relief agreed to at the decision point.

50. While the PRGF and IDA lending programs have been implemented with delays, there has been important progress with critically needed reforms in the last half year. Overall, the authorities were able to establish a track record of satisfactory policy implementation under the PRGF-supported program, evidenced by the completion of the first program review in early September and good progress toward meeting the conditions of the second review due in February 2004; overall progress in poverty reduction has been broadly acceptable as indicated by increased poverty-related expenditures and improvements in key social indicators since 2000; and most of the floating completion point conditions have been met.

51. The staffs support the authorities' request for waivers of two of the floating completion point conditions on civil service reform, once compensatory measures have been taken. The requirement to downsize by laying off 1,000 core civil servants has been compensated by more than 2,500 lay-offs elsewhere in the public sector. The failure to complete a list of job descriptions and design of a performance appraisal system has been replaced by the initiation of a comprehensive civil service reform with IDB support. Moreover, the government has formalized a hiring freeze in the core civil service until the IDB program is operational in 2005. It is expected that the two pending compensatory actions, namely, the 2003 wage increases to the core civil service consistent with the macroeconomic framework and the enactment of an organic budget law, will be implemented prior to Board consideration of the completion point.

\section{There are, however, concerns with some elements of the poverty reduction} strategy and with the outlook.

- The general paucity of data on poverty indicators makes it difficult to assess the extent to which poverty reduction objectives are being achieved. This is an area that the authorities will have to address. While progress has been made in reaching some of the PRSP objectives, it has been slow reflecting difficulties in establishing dialogue with the major opposition party and capacity constraints. These issues are gradually being resolved with the return of the opposition to parliament in May this year and the likelihood that the Poverty Monitoring Group will be fully staffed by end-year. However, the completion of the PRSP progress report is a key issue for the completion of the next PRGF-supported program review scheduled for February 2004.

- $\quad$ Provided the key structural reforms and governance improvements in the PRSP are implemented, the macroeconomic framework through 2022 is externally viable and fiscally sustainable. The sugar sector is the main uncertainty for the medium-term outlook, making it imperative to pursue reforms toward improving its competitiveness. It is also essential to strengthen the revenue yield to sustain poverty-reducing spending. 


\section{ISSUES FOR DISCUSSION}

\section{The staffs seek guidance from the Directors on the following points:}

- Do the Directors agree that Guyana should reach the completion point at this stage?

- Do the Directors agree that Guyana should continue to seek debt relief from its nonParis Club creditors within the framework of the HIPC Initiative and that the staffs should continue to monitor the delivery of debt relief from all creditors?

- $\quad$ Do Directors agree that assistance agreed at the decision point (as revised) will provide Guyana with a solid basis for debt sustainability over the medium term, as discussed in Section III?

- Do Directors agree with Guyana's plans to strengthen debt-management capacity and policy in the future (Appendix II)?

- Do Directors agree that sufficient assurances have been given by Guyana's other creditors to commit enhanced HIPC Initiative assistance to Guyana on an irrevocable basis? 


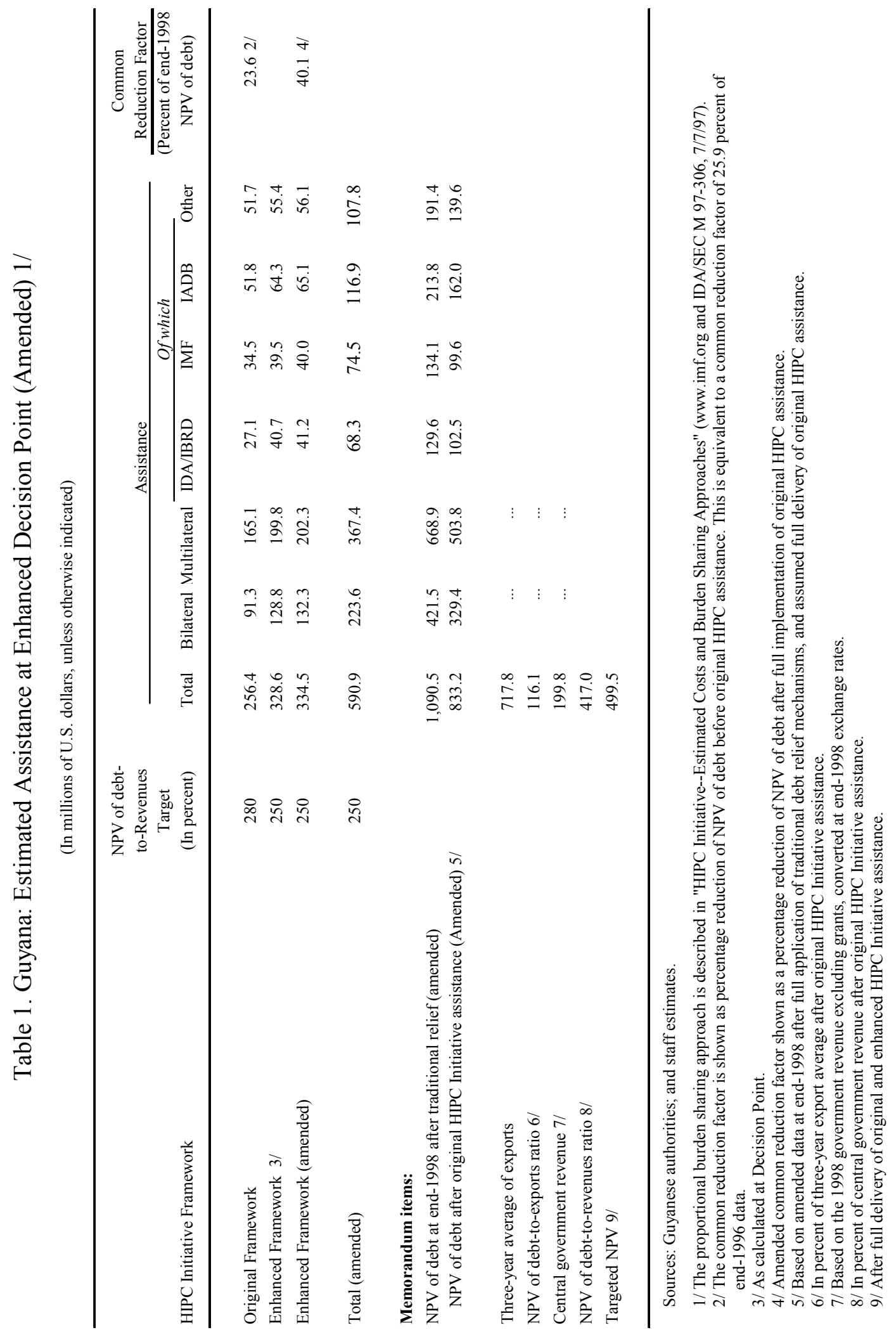


Table 2. Guyana: Net Present Value of External Debt Outstanding as of End-December 1998 1/ (In millions of U.S. dollars)

\begin{tabular}{|c|c|c|c|c|c|c|}
\hline & \multicolumn{2}{|c|}{ After Traditional Debt Relief } & \multicolumn{2}{|c|}{ After Original HIPC 2/ } & \multicolumn{2}{|c|}{ After Enhanced HIPC } \\
\hline & $\begin{array}{l}\text { As in E-HIPC Decision } \\
\text { Point Document 3/ }\end{array}$ & Revised & $\begin{array}{l}\text { As in E-HIPC Decision } \\
\text { Point Document 3/ }\end{array}$ & Revised & $\begin{array}{l}\text { As in E-HIPC Decision } \\
\text { Point Document }\end{array}$ & Revised \\
\hline Total debt & $1,085.3$ & $1,090.5$ & 827.7 & 833.1 & 499.4 & 498.6 \\
\hline Multilateral & 668.9 & 668.9 & 503.8 & 503.8 & 304.0 & 301.5 \\
\hline IDB & 213.8 & 213.8 & 162.0 & 162.0 & 97.8 & 97.0 \\
\hline IDA/IBRD & 129.6 & 129.6 & 102.5 & 102.5 & 61.9 & 61.4 \\
\hline IDA & 113.3 & 113.3 & 86.2 & 86.2 & 52.0 & 51.6 \\
\hline IBRD & 16.4 & 16.4 & 16.4 & 16.4 & 9.9 & 9.8 \\
\hline IMF & 134.1 & 134.1 & 99.6 & 99.6 & 60.1 & 59.6 \\
\hline $\mathrm{CMCF}$ & 102.0 & 102.0 & 72.8 & 72.8 & 43.9 & 43.6 \\
\hline EU/EIB & 34.5 & 34.5 & 26.5 & 26.5 & 16.0 & 15.8 \\
\hline CDB & 32.0 & 32.0 & 24.5 & 24.5 & 14.8 & 14.7 \\
\hline OPEC Fund & 19.6 & 19.6 & 13.4 & 13.4 & 8.1 & 8.0 \\
\hline IFAD & 3.3 & 3.3 & 2.4 & 2.4 & 1.5 & 1.5 \\
\hline Bilateral and commercial 3/ & 416.2 & 421.5 & 323.9 & 329.3 & 195.4 & 197.1 \\
\hline Paris Club & 317.2 & 319.5 & 234.3 & 236.5 & 141.4 & 141.6 \\
\hline Canada & 2.0 & 1.9 & 1.5 & 1.4 & 0.9 & 0.9 \\
\hline Denmark & 1.6 & 1.6 & 1.2 & 1.2 & 0.7 & 0.7 \\
\hline France & 1.8 & 1.7 & 1.3 & 1.3 & 0.8 & 0.8 \\
\hline Germany & 12.4 & 12.6 & 10.4 & 10.6 & 6.3 & 6.3 \\
\hline Japan & 1.3 & 1.3 & 1.3 & 1.3 & 0.8 & 0.8 \\
\hline Netherlands & 7.0 & 7.1 & 5.0 & 5.1 & 3.0 & 3.0 \\
\hline Russian Federation & 1.2 & 3.9 & 0.8 & 3.5 & 0.5 & 2.1 \\
\hline Trinidad and Tobago & 182.3 & 182.3 & 128.2 & 128.2 & 77.4 & 76.7 \\
\hline United Kingdom & 80.1 & 79.6 & 57.9 & 57.4 & 34.9 & 34.4 \\
\hline United States & 27.7 & 27.5 & 26.7 & 26.6 & 16.1 & 15.9 \\
\hline Other official bilateral & 51.1 & 52.3 & 43.7 & 44.8 & 26.4 & 26.8 \\
\hline Argentina & 2.2 & 2.9 & 1.7 & 2.4 & 1.0 & 1.4 \\
\hline Brazil & 3.8 & 3.8 & 3.8 & 3.8 & 2.3 & 2.3 \\
\hline Bulgaria & 0.0 & 0.3 & 0.0 & 0.3 & 0.0 & 0.2 \\
\hline $\mathrm{CDC} 4 /$ & 0.0 & $\ldots$ & 0.0 & 0.0 & 0.0 & 0.0 \\
\hline China & 8.3 & 7.9 & 8.0 & 7.7 & 4.8 & 4.6 \\
\hline Cuba & 0.0 & 0.3 & 0.0 & 0.3 & 0.0 & 0.2 \\
\hline DPRK & 0.7 & 0.3 & 0.6 & 0.1 & 0.4 & 0.1 \\
\hline India & 1.5 & 1.5 & 1.5 & 1.4 & 0.9 & 0.9 \\
\hline Kuwait & 12.1 & 12.1 & 9.2 & 9.2 & 5.6 & 5.5 \\
\hline Lybia & 10.6 & 11.0 & 8.2 & 8.6 & 4.9 & 5.1 \\
\hline United Arab Emirates & 1.8 & 4.4 & 1.4 & 4.0 & 0.8 & 2.4 \\
\hline Venezuela & 9.9 & 7.5 & 9.1 & 6.7 & 5.5 & 4.0 \\
\hline Yugoslavia & 0.3 & 0.3 & 0.2 & 0.2 & 0.1 & 0.1 \\
\hline Commercial creditors & 47.8 & 49.8 & 45.9 & 47.9 & 27.7 & 28.7 \\
\hline Canada & 0.3 & 0.3 & 0.3 & 0.3 & 0.2 & 0.2 \\
\hline India & 0.0 & 0.1 & 0.0 & 0.1 & 0.0 & 0.0 \\
\hline Norway & 0.0 & 2.0 & 0.0 & 2.0 & 0.0 & 1.2 \\
\hline United Kingdom & 10.4 & 10.5 & 8.7 & 8.8 & 5.2 & 5.3 \\
\hline United States & 0.5 & 0.3 & 0.2 & 0.0 & 0.1 & 0.0 \\
\hline EPDS 5/ & 4.9 & 6.5 & 5.0 & 6.6 & 3.0 & 3.9 \\
\hline Bonds & 31.7 & 30.1 & 31.7 & 30.1 & 19.1 & 18.0 \\
\hline
\end{tabular}

Sources: Guyanese authorities; and Fund staff estimates.

1/ Using 1998 CIRR and discount rates. The NPV of debt for bilateral and commercial creditors reflects the 1996 Paris Club stock-of-debt operation on Naples terms with comparability of treatment for non Paris Club creditors at end-1998.

2/ Assumes a stock-of-debt operation on Lyon terms by Paris Club creditors, and comparable action by other official bilateral and commercial creditors on eligible debt (pre-cutoff and non-ODA).

3/ Modified numbers from the decision point document due to correction for summation errors and data revision.

4/ CDC was reclassified as a commercial creditor.

5 / Modified numbers from the decision point due to new data. 
Table 3. Guyana: Selected Economic and Financial Indicators

\begin{tabular}{|c|c|c|c|c|c|c|c|c|c|c|}
\hline & \multicolumn{2}{|c|}{ Actual } & \multicolumn{5}{|c|}{ Projections } & \multirow[b]{2}{*}{2008} & \multicolumn{2}{|c|}{ Averages } \\
\hline & 2001 & $\overline{2002}$ & 2003 & 2004 & 2005 & 2006 & 2007 & & $2003-12$ & $2013-22$ \\
\hline \multicolumn{11}{|c|}{ (Percentage change) } \\
\hline \multicolumn{11}{|l|}{ Production and prices } \\
\hline Real GDP (factor cost) & 2.3 & 1.1 & -0.2 & 2.0 & 0.8 & 1.8 & 2.9 & 2.9 & 2.0 & 2.7 \\
\hline Nominal GDP (market prices) & 2.6 & 3.3 & 3.6 & 6.4 & 3.5 & 2.1 & 4.0 & 4.0 & 5.0 & 5.8 \\
\hline GDP deflator (factor cost) & 1.5 & 3.8 & 4.7 & 4.6 & 2.4 & 0.3 & 1.0 & 1.0 & 2.8 & 3.1 \\
\hline Consumer prices (average) & 2.7 & 5.3 & 5.8 & 4.6 & 3.5 & 3.0 & 3.0 & 3.0 & 3.5 & 3.0 \\
\hline Consumer prices (end of period) & 1.5 & 6.1 & 6.0 & 4.0 & 3.0 & 3.0 & 3.0 & 3.0 & 3.0 & 3.0 \\
\hline Real GDP per capita & 1.3 & 0.1 & -1.2 & 1.0 & -0.2 & 0.8 & 1.9 & 1.9 & 1.1 & 1.8 \\
\hline \multicolumn{11}{|c|}{ (In percent of GDP) } \\
\hline \multicolumn{11}{|l|}{ National accounts } \\
\hline Investment & 21.9 & 20.0 & 23.4 & 28.2 & 27.5 & 23.9 & 23.5 & 23.6 & 23.7 & 21.6 \\
\hline Private sector & 8.2 & 7.4 & 6.6 & 7.0 & 8.0 & 10.0 & 10.0 & 11.0 & 9.5 & 11.0 \\
\hline Public sector & 13.7 & 12.6 & 16.8 & 21.2 & 19.5 & 13.9 & 13.5 & 12.6 & 14.2 & 10.6 \\
\hline National saving & 3.8 & 5.2 & 6.5 & 9.4 & 9.1 & 9.1 & 10.3 & 11.4 & 9.3 & 11.2 \\
\hline Private sector & 5.1 & 6.5 & 6.3 & 5.4 & 5.4 & 4.7 & 4.5 & 5.5 & 4.3 & 4.4 \\
\hline Public sector & -1.3 & -1.3 & 0.2 & 4.0 & 3.6 & 4.4 & 5.7 & 5.9 & 5.0 & 6.8 \\
\hline External current account balance(excluding transfers) $2 / 3$ / & -18.1 & -14.8 & -16.9 & -18.7 & -18.4 & -14.8 & -13.3 & -12.2 & -14.4 & -10.4 \\
\hline \multicolumn{11}{|l|}{ Nonfinancial public sector } \\
\hline Revenue & 33.1 & 33.2 & 33.4 & 35.5 & 36.5 & 37.8 & 38.1 & 37.3 & 36.7 & 36.4 \\
\hline Expenditure & 48.5 & 47.5 & 47.3 & 52.6 & 52.4 & 47.3 & 45.9 & 44.0 & 45.9 & 40.2 \\
\hline Current & 34.5 & 34.6 & 33.5 & 31.5 & 32.9 & 33.4 & 32.3 & 31.4 & 31.7 & 29.6 \\
\hline Capital & 14.0 & 13.0 & 13.9 & 21.2 & 19.5 & 13.9 & 13.5 & 12.6 & 14.2 & 10.6 \\
\hline Saving & -1.4 & -1.3 & -0.1 & 4.0 & 3.6 & 4.4 & 5.7 & 5.9 & 5.0 & 6.8 \\
\hline Overall balance (before grants) $1 / 2$ / & -15.3 & -14.3 & -13.9 & -17.2 & -15.9 & -9.5 & -7.8 & -6.7 & -9.2 & -3.8 \\
\hline Grants (including HIPC relief) 3/ & 8.3 & 8.4 & 4.8 & 6.7 & 6.9 & 6.0 & 5.3 & 5.1 & 4.9 & 2.1 \\
\hline Overall balance (after grants) $1 / 2 /$ & -7.0 & -5.9 & -9.1 & -10.4 & -8.9 & -3.4 & -2.5 & -1.7 & -4.3 & -1.7 \\
\hline Statistical discrepancy 4/ & -0.7 & 1.1 & 0.0 & 0.0 & 0.0 & 0.0 & 0.0 & 0.0 & 0.0 & 0.0 \\
\hline Net external financing & 6.9 & 2.5 & 6.4 & 4.1 & 6.2 & 5.8 & 5.7 & 3.6 & 4.0 & 0.9 \\
\hline Net domestic financing & 0.8 & 1.3 & 1.6 & 2.7 & -0.5 & -3.2 & -3.2 & -2.0 & -0.6 & 0.8 \\
\hline PRGF financing & 0.0 & 1.0 & 1.1 & 3.6 & 3.3 & 0.8 & 0.0 & 0.0 & 0.9 & 0.0 \\
\hline (In millions of U.S. dollars) & 0.0 & 7.3 & 8.5 & 27.4 & 25.6 & 6.4 & 0.0 & 0.0 & 6.8 & 0.0 \\
\hline Total public sector debt (end of period) & 200.7 & 203.1 & 185.9 & 189.5 & 194.4 & 195.7 & 193.9 & 193.0 & 187.4 & 147.8 \\
\hline External 2/ & 171.1 & 171.4 & 154.8 & 160.1 & 166.4 & 171.6 & 174.1 & 174.1 & 165.6 & 135.6 \\
\hline Domestic 5/ & 29.6 & 31.7 & 31.1 & 29.4 & 27.9 & 24.0 & 19.8 & 18.8 & 21.8 & 12.2 \\
\hline \multicolumn{11}{|c|}{ (Percentage change relative to broad money at the beginning of the year) } \\
\hline \multicolumn{11}{|l|}{ Money and credit (end of period) } \\
\hline Domestic credit of the banking system & 2.6 & 2.2 & 6.3 & -0.9 & -4.5 & 5.8 & 2.5 & 2.5 & $\ldots$ & $\ldots$ \\
\hline Public sector (net) & 1.9 & 2.4 & 15.4 & -3.2 & -4.9 & 4.3 & -0.6 & -0.6 & $\ldots$ & $\ldots$ \\
\hline Private sector & 0.7 & -0.1 & -9.2 & 2.3 & 0.5 & 1.4 & 3.1 & 3.1 & $\ldots$ & $\ldots$ \\
\hline Broad money & 8.9 & 5.5 & 5.6 & 6.2 & 3.8 & 4.8 & 5.9 & 5.9 & $\ldots$ & $\ldots$ \\
\hline \multicolumn{11}{|l|}{ Interest rates (end of period) } \\
\hline Treasury bills ( 91 days) & 6.3 & 3.9 & $\ldots$ & $\ldots$ & $\ldots$ & $\ldots$ & $\ldots$ & $\ldots$ & $\ldots$ & $\ldots$ \\
\hline Commercial lending rate & 16.8 & 16.3 & $\ldots$ & $\ldots$ & $\ldots$ & $\ldots$ & $\ldots$ & $\ldots$ & $\ldots$ & $\ldots$ \\
\hline Small savings rate & 6.7 & 4.3 & $\ldots$ & $\ldots$ & $\ldots$ & $\ldots$ & $\cdots$ & $\cdots$ & $\ldots$ & $\cdots$ \\
\hline (In milli & fU.S. do & s, unles & therwise & dicated; & of peric & & & & & \\
\hline External sector & & & & & & & & & & \\
\hline Overall balance of payments & -12.3 & 20.0 & -20.2 & -28.4 & -7.0 & 6.4 & 42.8 & 34.4 & 8.9 & 13.2 \\
\hline Gross official reserves & 285 & 279.8 & 262.7 & 241.1 & 240.6 & 239.4 & 269.8 & 294.9 & 285.0 & 451.0 \\
\hline Months of imports 6/ & 4.3 & 4.2 & 3.7 & 3.5 & 3.5 & 3.4 & 3.8 & 4.0 & 3.8 & 4.0 \\
\hline & (In per & t; unless & herwise $\mathrm{i}$ & licated) & & & & & & \\
\hline Debt-service ratios & & & & & & & & & & \\
\hline Exports of goods and nonfactor services & & & & & & & & & & \\
\hline Before original HIPC assistance & 14.6 & 13.6 & 14.7 & 14.8 & 14.6 & 14.8 & 14.2 & 13.6 & 13.2 & 8.8 \\
\hline After original HIPC assistance 7/ & 10.3 & 9.5 & 11.1 & 4.7 & 4.5 & 4.9 & 5.0 & 5.4 & 5.2 & 5.1 \\
\hline Central government revenue & & & & & & & & & & \\
\hline Before original HIPC assistance & 43.9 & 39.8 & 44.1 & 43.0 & 40.2 & 38.7 & 36.9 & 34.6 & 35.1 & 20.6 \\
\hline After original HIPC assistance 7/ & 30.9 & 27.7 & 33.4 & 13.7 & 12.5 & 12.7 & 13.0 & 13.7 & 13.8 & 11.9 \\
\hline Real effective exchange rate 8 / & -4.2 & -9.5 & $\ldots$ & $\ldots$ & $\ldots$ & $\ldots$ & $\ldots$ & $\ldots$ & $\ldots$ & $\ldots$ \\
\hline Memorandum items: & & & & & & & & & & \\
\hline Nominal GDP (G\$ billion) & 133.4 & 137.8 & 142.8 & 152.5 & 158.0 & 161.9 & 168.5 & 176.6 & 175.5 & 278.1 \\
\hline Guyana dollar/U.S. dollar 9/ & 187.6 & 190.7 & 193.6 & 198.1 & 202.3 & 204.8 & 206.8 & 206.8 & 207.8 & 207.8 \\
\hline
\end{tabular}

Sources: Data provided by the Guyanese authorities; and Fund staff estimates and projections.

1/ Beginning in 2004 reflects interest payments after o-HIPC and e-HIPC debt relief.

2/ Assumes that e-HIPC completion point is reached in December 2003

3 / Includes only o-HIPC debt relief, except in 2000 and 2001 when e-HIPC interim assistance is also included.

4/ A negative number indicates an over-financing of the deficit when measured from below the line.

5/ Based on monetary data and nonbank holdings of government debt.

6/ Imports of goods and nonfactor services, excluding escrow account movements.

7/ After beyond e-HIPC for 2004 onwards.

8 / Twelve-month rate of change, depreciation (-).

9/ Period average. 
Table 4. Guyana: Central Government

\begin{tabular}{|c|c|c|c|c|c|c|c|c|c|c|}
\hline & \multicolumn{2}{|c|}{ Actual } & \multicolumn{5}{|c|}{$\overline{\text { DSA }}$} & \multirow[b]{2}{*}{2008} & \multicolumn{2}{|c|}{ Averages } \\
\hline & 2001 & 2002 & 2003 & 2004 & 2005 & 2006 & 2007 & & $2003-12$ & $2013-22$ \\
\hline \multicolumn{11}{|c|}{ (In millions of Guyana dollars) } \\
\hline Total revenue & 41,218 & 44,565 & 44,299 & 48,159 & 51,693 & 54,183 & 56,583 & 59,078 & 58,012 & 93,144 \\
\hline $\begin{array}{l}\text { Tax } \\
\text { Income taxes } \\
\text { Consumption taxes } \\
\text { Trade taxes } \\
\text { Other }\end{array}$ & $\begin{array}{r}37,773 \\
16,721 \\
14,376 \\
4,790 \\
1,886\end{array}$ & $\begin{array}{r}40,800 \\
19,043 \\
15,102 \\
4,634 \\
2,021\end{array}$ & $\begin{array}{r}40,393 \\
18,948 \\
14,973 \\
4,482 \\
1,990\end{array}$ & $\begin{array}{r}43,501 \\
19,736 \\
15,917 \\
4,927 \\
2,922\end{array}$ & $\begin{array}{r}46,133 \\
20,926 \\
16,848 \\
5,261 \\
3,098\end{array}$ & $\begin{array}{r}48,471 \\
22,043 \\
17,610 \\
5,555 \\
3,263\end{array}$ & $\begin{array}{r}50,582 \\
23,079 \\
18,490 \\
5,897 \\
3,117\end{array}$ & $\begin{array}{r}53,038 \\
24,440 \\
19,378 \\
6,180 \\
3,041\end{array}$ & $\begin{array}{r}52,359 \\
24,089 \\
19,048 \\
6,013 \\
3,208\end{array}$ & $\begin{array}{r}86,354 \\
40,513 \\
30,525 \\
9,735 \\
5,580\end{array}$ \\
\hline Nontax & 3,445 & 3,765 & 3,906 & 4,657 & 5,560 & 5,712 & 6,000 & 6,040 & 5,654 & 6,791 \\
\hline Total expenditure & 63,641 & 64,056 & 66,307 & 75,720 & 78,746 & 71,563 & 71,990 & 73,582 & 75,811 & 107,818 \\
\hline Current & 47,130 & 48,379 & 49,454 & 47,951 & 51,964 & 54,072 & 54,464 & 55,415 & 55,572 & 82,132 \\
\hline $\begin{array}{l}\text { Noninterest expenditure } \\
\text { Severance payments } \\
\text { Personal emoluments } \\
\text { Other goods and services 1/ } \\
\text { Transfer payments } \\
\text { Transfers to Linmine }\end{array}$ & $\begin{array}{r}35,456 \\
0 \\
14,833 \\
9,057 \\
9,568 \\
1,997\end{array}$ & $\begin{array}{r}37,526 \\
441 \\
15,830 \\
9,718 \\
9,630 \\
1,907\end{array}$ & $\begin{array}{r}41,224 \\
1,199 \\
16,852 \\
11,319 \\
10,197 \\
1,658\end{array}$ & $\begin{array}{r}42,580 \\
0 \\
17,843 \\
13,466 \\
11,271 \\
0\end{array}$ & $\begin{array}{r}44,752 \\
0 \\
18,366 \\
14,719 \\
11,667 \\
0\end{array}$ & $\begin{array}{r}46,816 \\
0 \\
18,874 \\
15,930 \\
12,012 \\
0\end{array}$ & $\begin{array}{r}47,067 \\
0 \\
19,465 \\
15,220 \\
12,381 \\
0\end{array}$ & $\begin{array}{r}48,308 \\
0 \\
20,041 \\
16,173 \\
12,093 \\
0\end{array}$ & $\begin{array}{r}48,665 \\
120 \\
19,772 \\
16,199 \\
12,408 \\
166\end{array}$ & $\begin{array}{r}74,285 \\
0 \\
26,534 \\
28,701 \\
19,050 \\
0\end{array}$ \\
\hline Primary balance & 5,762 & 7,039 & 3,075 & 5,579 & 6,941 & 7,367 & 9,516 & 10,771 & 9,347 & 18,860 \\
\hline $\begin{array}{l}\text { Interest payments } \\
\text { External interest 2/ } \\
\text { Domestic interest }\end{array}$ & $\begin{array}{r}11,674 \\
6,842 \\
4,832\end{array}$ & $\begin{array}{r}10,853 \\
6,566 \\
4,287\end{array}$ & $\begin{array}{l}8,229 \\
5,303 \\
2,927\end{array}$ & $\begin{array}{l}5,371 \\
2,513 \\
2,858\end{array}$ & $\begin{array}{l}7,212 \\
2,643 \\
4,569\end{array}$ & $\begin{array}{l}7,256 \\
2,755 \\
4,501\end{array}$ & $\begin{array}{l}7,397 \\
2,956 \\
4,441\end{array}$ & $\begin{array}{l}7,108 \\
3,046 \\
4,062\end{array}$ & $\begin{array}{l}6,907 \\
3,073 \\
3,834\end{array}$ & $\begin{array}{l}7,848 \\
3,831 \\
4,016\end{array}$ \\
\hline Capital expenditure and net lending 1 / & 16,511 & 15,677 & 16,853 & 27,769 & 26,782 & 17,492 & 17,526 & 18,166 & 20,239 & 25,685 \\
\hline Current balance & $-5,912$ & $-3,814$ & $-5,154$ & 208 & -270 & 111 & 2,119 & 3,663 & 2,440 & 11,012 \\
\hline Overall balance & $-22,423$ & $-19,491$ & $-22,007$ & $-27,561$ & $-27,052$ & $-17,380$ & $-15,407$ & $-14,503$ & $-17,799$ & $-14,673$ \\
\hline $\begin{array}{l}\text { Grants 3/ } \\
\text { HIPC Relief } \\
\text { Other }\end{array}$ & $\begin{array}{r}10,903 \\
7,937 \\
2,966\end{array}$ & $\begin{array}{r}11,249 \\
8,579 \\
2,670\end{array}$ & $\begin{array}{l}7,237 \\
3,537 \\
3,700\end{array}$ & $\begin{array}{r}10,270 \\
4,452 \\
5,818\end{array}$ & $\begin{array}{r}10,977 \\
4,211 \\
6,767\end{array}$ & $\begin{array}{l}9,783 \\
3,694 \\
6,089\end{array}$ & $\begin{array}{l}9,005 \\
2,804 \\
6,200\end{array}$ & $\begin{array}{l}8,917 \\
2,295 \\
6,622\end{array}$ & $\begin{array}{l}8,409 \\
2,367 \\
6,042\end{array}$ & $\begin{array}{r}5,593 \\
0 \\
5,593\end{array}$ \\
\hline Overall balance after grants 4/ & $-11,520$ & $\begin{array}{r}-8,243 \\
1,828\end{array}$ & $-14,770$ & $-17,292$ & $-16,075$ & $\begin{array}{r}-7,597 \\
0\end{array}$ & $\begin{array}{r}-6,403 \\
0\end{array}$ & & $\begin{array}{r}-9,390 \\
0\end{array}$ & $-9,080$ \\
\hline $\begin{array}{l}\text { Statistical discrepancy 5/ } \\
\text { Net foreign financing }\end{array}$ & $\begin{array}{r}-723 \\
7,978\end{array}$ & $\begin{array}{l}1,828 \\
3,734\end{array}$ & $\begin{array}{r}0 \\
8,081\end{array}$ & $\begin{array}{r}0 \\
6,297\end{array}$ & $\begin{array}{r}0 \\
9,736\end{array}$ & $\begin{array}{r}0 \\
9,422\end{array}$ & $\begin{array}{r}0 \\
9,578\end{array}$ & $\begin{array}{r}0 \\
6,438\end{array}$ & $\begin{array}{r}0 \\
6,649\end{array}$ & $\begin{array}{r}0 \\
2,397\end{array}$ \\
\hline Disbursements & 12,929 & 8,623 & 10,749 & 12,637 & 12,151 & 11,639 & 12,422 & 10,727 & 10,885 & 9,652 \\
\hline Amortization 6/ & $-4,951$ & $-4,889$ & $-2,667$ & $-3,570$ & $-3,431$ & $-3,253$ & $-3,688$ & $-4,289$ & $-4,248$ & $-7,255$ \\
\hline Rescheduling & 0 & 0 & 0 & 0 & 0 & 0 & 0 & 0 & 0 & 0 \\
\hline GUYSUCO escrow account financin & & 0 & 0 & $-2,771$ & 1,016 & 1,036 & 844 & 0 & 12 & 0 \\
\hline Net domestic financing & 3,542 & 2,680 & 5,050 & 5,579 & 1,143 & $-3,159$ & $-3,175$ & -851 & 1,382 & 6,683 \\
\hline PRGF 7/ & 0 & 0 & 1,639 & 5,416 & 5,196 & 1,335 & 0 & 0 & 1,359 & 0 \\
\hline In U.S. dollars & 0 & 7 & 8.5 & 27.4 & 25.6 & 6.4 & 0.0 & 0.0 & 6.8 & 0.0 \\
\hline \multicolumn{11}{|c|}{ (In percent of GDP) } \\
\hline Revenue & 31.3 & 32.4 & 31.0 & 31.6 & 32.7 & 33.5 & 33.6 & 33.5 & 33.0 & 33.5 \\
\hline Expenditure & 48.4 & 46.5 & 46.4 & 49.7 & 49.8 & 44.2 & 42.7 & 41.7 & 43.6 & 38.8 \\
\hline Current & 35.8 & 35.1 & 34.6 & 31.5 & 32.9 & 33.4 & 32.3 & 31.4 & 31.8 & 29.6 \\
\hline Interest payments $2 /$ & 8.9 & 7.9 & 5.8 & 3.5 & 4.6 & 4.5 & 4.4 & 4.0 & 4.0 & 2.8 \\
\hline Noninterest payments & 27.0 & 27.2 & 28.9 & 27.9 & 28.3 & 28.9 & 27.9 & 27.4 & 27.8 & 26.7 \\
\hline \multicolumn{11}{|l|}{ Of which } \\
\hline Severance payments & 0.0 & 0.3 & 0.8 & 0.0 & 0.0 & 0.0 & 0.0 & 0.0 & 0.1 & 0.0 \\
\hline Wages & 11.3 & 11.5 & 11.8 & 11.7 & 11.6 & 11.7 & 11.6 & 11.4 & 11.3 & 9.6 \\
\hline E-HIPC interim assistance & 0.0 & 0.0 & 0.0 & 0.0 & 0.0 & 0.0 & 0.0 & 0.0 & 0.0 & 0.0 \\
\hline $\begin{array}{l}\text { Capital } \\
\text { Of which }\end{array}$ & 12.6 & 11.4 & 11.8 & 18.2 & 17.0 & 10.8 & 10.4 & 10.3 & 11.8 & 9.2 \\
\hline E-HIPC interim assistance & 2.0 & 0.0 & 0.0 & 0.0 & 0.0 & 0.0 & 0.0 & 0.0 & 0.0 & 0.0 \\
\hline Primary balance & 4.4 & 5.1 & 2.2 & 3.7 & 4.4 & 4.6 & 5.6 & 6.1 & 5.2 & 6.8 \\
\hline Current balance & -4.5 & -2.8 & -3.6 & 0.1 & -0.2 & 0.1 & 1.3 & 2.1 & 1.2 & 3.9 \\
\hline Overall balance & -17.0 & -14.2 & -15.4 & -18.1 & -17.1 & -10.7 & -9.1 & -8.2 & -10.6 & -5.3 \\
\hline Grants 3 / & 8.3 & 8.2 & 5.1 & 6.7 & 6.9 & 6.0 & 5.3 & 5.1 & 4.9 & 2.1 \\
\hline $\begin{array}{l}\text { Of which } \\
\text { HIPC relief }\end{array}$ & & & & & & & & & & \\
\hline $\begin{array}{l}\text { HIPC relief } \\
\text { Overall balance after grants } 4 /\end{array}$ & $\begin{array}{r}6.0 \\
\mathbf{- 8 . 8}\end{array}$ & $\begin{array}{r}6.2 \\
-6.0\end{array}$ & $\begin{array}{r}2.5 \\
-10.3\end{array}$ & $\begin{array}{r}2.9 \\
-11.3\end{array}$ & $\begin{array}{r}2.7 \\
-10.2\end{array}$ & 2.3 & $\begin{array}{r}1.7 \\
\mathbf{- 3 . 8}\end{array}$ & 1.3 & $\begin{array}{r}1.5 \\
-5.7\end{array}$ & $\begin{array}{r}0.0 \\
-3.3\end{array}$ \\
\hline Statistical discrepancy & $\begin{array}{l}-\mathbf{- 0 . 0} \\
-0.5\end{array}$ & $\begin{array}{r}-0.0 \\
0.0\end{array}$ & $\begin{array}{r}-10.5 \\
0.0\end{array}$ & $\begin{array}{r}-11.3 \\
0.0\end{array}$ & $\begin{array}{r}-10.2 \\
0.0\end{array}$ & $\begin{array}{r}-4.1 \\
0.0\end{array}$ & $\begin{array}{r}-3.0 \\
0.0\end{array}$ & $\begin{array}{r}-5.2 \\
0.0\end{array}$ & $\begin{array}{r}-5.1 \\
0.0\end{array}$ & $\begin{array}{r}-5.5 \\
0.0\end{array}$ \\
\hline Net foreign financing & 6.1 & 2.7 & 5.7 & 4.1 & 6.2 & 5.8 & 5.7 & 3.6 & 4.0 & 0.9 \\
\hline Disbursements & 9.8 & 6.3 & 7.5 & 8.3 & 7.7 & 7.2 & 7.4 & 6.1 & 6.4 & 3.5 \\
\hline Amortization & -3.8 & -3.5 & -1.9 & -2.3 & -2.2 & -2.0 & -2.2 & -2.4 & -2.4 & -2.6 \\
\hline Rescheduling & 0.0 & 0.0 & 0.0 & 0.0 & 0.0 & 0.0 & 0.0 & 0.0 & 0.0 & 0.0 \\
\hline GUYSUCO escrow account financin & & 0.0 & 0.0 & -1.8 & 0.6 & 0.6 & 0.5 & 0.0 & 0.0 & 0.0 \\
\hline Net domestic financing $5 /$ & 2.7 & 1.9 & 3.5 & 3.7 & 0.7 & -2.0 & -1.9 & -0.5 & 0.8 & 2.3 \\
\hline PRGF 7/ & 0.0 & 0.0 & 1.1 & 3.6 & 3.3 & 0.8 & 0.0 & 0.0 & 0.9 & 0.0 \\
\hline \multicolumn{11}{|l|}{ Memorandum item: } \\
\hline $\begin{array}{l}\text { Nominal GDP at market prices } \\
\text { (In millions of Guyana dollars) }\end{array}$ & 131,553 & 137,748 & 142,768 & 152,462 & 157,996 & 161,855 & 168,476 & 176,563 & 175,529 & 278,140 \\
\hline
\end{tabular}

Sources: Guyanese authorities; and Fund staff estimates.

$1 /$ Includes poverty reducing spending financed from HIPC resources.

3/ Beginning in 2004 includes HIPC assistance only in the form of grants and CMCF HIPC assistance transferred by the Bank of Guvana to the central government.

4/ Beginning in 2004 reflects interest payments after debt stock reduction and HIPC assistance provided only in the form of grants and CMCF HIPC assistance transferred by the Bank of Guyana to the central government

5/ A negative number indicates an over-financing of the fiscal deficit when measured from below the line.

6/ Beginning in 2004 reflects principal payments after debt stock reduction and HIPC assistance provided in the form of debt rescheduling.

7/ To be filled with PRGF disbursements in 2002-06. 
Table 5. Guyana: Balance of Payments

\begin{tabular}{|c|c|c|c|c|c|c|c|c|c|}
\hline & \multicolumn{2}{|c|}{ Actual } & \multicolumn{5}{|c|}{ DSA } & \multicolumn{2}{|c|}{ Averages } \\
\hline & 2001 & 2002 & 2003 & 2004 & 2005 & 2006 & 2007 & $2008-12$ & $2013-22$ \\
\hline \multicolumn{10}{|c|}{ (In millions of U.S. dollars) } \\
\hline $\begin{array}{l}\text { Current account } 1 \text { / } \\
\text { (excluding official transfers) }\end{array}$ & -129 & -107 & -125 & -142 & -142 & -115 & -105 & -115 & -138 \\
\hline Merchandise trade (net) & -94 & -68 & -101 & -136 & -141 & -126 & -121 & -124 & -172 \\
\hline Exports (f.o.b.) & 490 & 495 & 502 & 512 & 494 & 473 & 483 & 533 & 687 \\
\hline $\begin{array}{l}\text { Of which } \\
\text { Bauxite }\end{array}$ & 61 & 35 & 45 & 51 & 59 & 64 & 65 & Of which & 92 \\
\hline Sugar & 109 & 119 & 134 & 143 & 145 & 150 & 152 & 165 & 195 \\
\hline Rice & 50 & 46 & 45 & 46 & 47 & 49 & 49 & 52 & 60 \\
\hline Gold & 127 & 135 & 109 & 104 & 76 & 41 & 42 & 53 & 89 \\
\hline Timber & 16 & 24 & 21 & 23 & 26 & 28 & 30 & 36 & 50 \\
\hline Imports (c.i.f.) & 584 & 563 & 602 & 648 & 636 & 599 & 604 & 657 & 859 \\
\hline Services (net) & -79 & -79 & -69 & -52 & -51 & -49 & -50 & -32 & -61 \\
\hline Nonfactor services & -20 & -26 & -26 & -27 & -27 & -27 & -28 & -21 & -37 \\
\hline Factor services $1 /$ & -59 & -53 & -43 & -25 & -24 & -21 & -22 & -21 & -24 \\
\hline Net private transfers & 44 & 40 & 45 & 45 & 50 & 60 & 66 & 62 & 95 \\
\hline Capital and financial account $2 / 3$ / & 118 & 90 & 105 & 114 & 135 & 121 & 148 & 134 & 151 \\
\hline Capital account & & $\mathbf{0}$ & $\mathbf{0}$ & $\mathbf{0}$ & $\mathbf{0}$ & $\mathbf{0}$ & $\mathbf{0}$ & $\mathbf{0}$ & $\mathbf{0}$ \\
\hline Financial account $2 / 3$ / & 118 & 121 & 105 & 114 & 135 & 121 & 148 & 134 & 134 \\
\hline Nonfinancial public sector (net) 2/3/ & 73 & 54 & 75 & 66 & 86 & 52 & 76 & 134 & 35 \\
\hline Net official transfers $2 /$ & 24 & 33 & 39 & 33 & 36 & 32 & 29 & 54 & 26 \\
\hline Net official borrowing $3 /$ & 43 & 12 & 30 & 48 & 45 & 15 & 43 & 30 & 8 \\
\hline Project loans & 39 & 32 & 43 & 41 & 42 & 46 & 46 & 24 & 44 \\
\hline Program loans & 26 & 7 & 12 & 23 & 18 & 10 & 13 & 46 & 0 \\
\hline \multicolumn{10}{|l|}{ Restructured stock } \\
\hline Amortization 3/ & -22 & -26 & -26 & -16 & -15 & -41 & -16 & -23 & -36 \\
\hline Other public sector (net) & 6 & 8 & 7 & -14 & 5 & 5 & 4 & 0 & 0 \\
\hline Private sector (net) & 45 & 35 & 30 & 48 & 49 & 69 & 72 & 80 & 116 \\
\hline Change in NFA of commercial banks & -11 & -8 & -18 & 0 & 0 & 0 & 0 & 0 & 0 \\
\hline Other short-term flows/trade credits & 0 & 0 & 0 & 0 & 0 & 0 & 0 & 0 & 0 \\
\hline Foreign direct investment (net) & 56 & 44 & 48 & 48 & 49 & 69 & 72 & 80 & 116 \\
\hline Errors and omissions & 19 & 9 & $\mathbf{0}$ & $\mathbf{0}$ & $\mathbf{0}$ & $\mathbf{0}$ & $\mathbf{0}$ & $\mathbf{0}$ & $\mathbf{0}$ \\
\hline Overall balance & 8 & -9 & -20 & -28 & -7 & 6 & 43 & 19 & 13 \\
\hline Financing & -8 & 9 & 20 & 28 & 7 & -6 & -43 & -19 & -13 \\
\hline Bank of Guyana net foreign assets & -16 & -5 & 3 & 2 & -19 & -13 & -42 & -19 & -14 \\
\hline Assets (increase -) & 12 & 5 & 17 & 22 & 1 & 1 & -30 & -15 & -14 \\
\hline Liabilities & -28 & -10 & -14 & -20 & -19 & -14 & -12 & -4 & 0 \\
\hline \multicolumn{10}{|l|}{ Of which } \\
\hline Use of IMF credit (net) & -20 & -9 & -14 & -20 & -19 & -14 & -12 & -4 & 0 \\
\hline Change in NFPS arrears & 0 & 0 & 0 & 0 & 0 & 0 & 0 & 0 & 0 \\
\hline Exceptional financing 4/ & 9 & 14 & 8 & 0 & 0 & 0 & 0 & 0 & 0 \\
\hline Debt relief (HIPC from 1999) 4/ & 9 & 14 & 8 & 0 & 0 & 0 & 0 & 0 & 0 \\
\hline Debt-stock restructuring & 0 & 0 & 0 & 0 & 0 & 0 & 0 & 0 & 0 \\
\hline Debt forgiveness & 0 & 0 & 0 & 0 & 0 & 0 & 0 & 0 & 0 \\
\hline Rescheduling (Paris Club 1999) & 0 & 0 & 0 & 0 & 0 & 0 & 0 & 0 & 0 \\
\hline Gap 5/ & 0 & 0 & 9 & 27 & 26 & 6 & 0 & 0 & 0 \\
\hline \multicolumn{10}{|c|}{ (Percentage change) } \\
\hline Export volume & -6 & -1 & 1 & -3 & -6 & -4 & 4 & 3 & 3 \\
\hline Export prices & 3 & 2 & 1 & 5 & 3 & -1 & -2 & 1 & 1 \\
\hline Import volume & 0 & -1 & -5 & -3 & 1 & -2 & 0 & 3 & 3 \\
\hline Import prices & 0 & -1 & 4 & 0 & 0 & -1 & 0 & 1 & 1 \\
\hline External terms of trade & 4 & 3 & -3 & 5 & 3 & 0 & -2 & 0 & 0 \\
\hline
\end{tabular}

Sources: Bank of Guyana; Statistical Bureau of Guyana; Ministry of Finance; and Fund staff estimates and projections.

1/ Including scheduled interest payments before HIPC Initiative for years through 2003. Including scheduled interest payments after e-HIPC since 2003. 2/ Including interim assistance under the enhanced HIPC Initiative through 2003.

3/ Including scheduled amortization before HIPC Initiative through 2003. Including scheduled amortization after e-HIPC after 2003.

4/ Including debt relief provided under o-HIPC for years before 2003. Including o-HIPC debt relief provided through flow rescheduling after 2003.

Non-Paris Club creditors are assumed to provide comparable debt relief as Paris Club creditors.

5/ To be filled with PRGF disbursements in 2003-06. 
Table 6. Guyana: Nominal and Net Present Value of External Debt Outstanding at End-2002 1/

(In millions of U.S. dollars)

\begin{tabular}{|c|c|c|c|c|}
\hline & \multicolumn{2}{|c|}{ Legal Situation 2/ } & \multicolumn{2}{|c|}{ NPV of Debt 3/ } \\
\hline & Nominal Debt & NPV of Debt & After Original HIPC relief & Percent of Total \\
\hline Total & $1,324.5$ & 982.2 & 878.5 & 100.0 \\
\hline Multilateral & 832.3 & 568.3 & 568.3 & 64.7 \\
\hline IDB & 359.7 & 247.1 & 247.1 & 28.1 \\
\hline IDA/IBRD & 199.2 & 110.0 & 110.0 & 12.5 \\
\hline IDA & 196.8 & 107.5 & 107.5 & 12.2 \\
\hline IBRD & 2.4 & 2.4 & 2.4 & 0.3 \\
\hline IMF & 96.2 & 70.5 & 70.5 & 8.0 \\
\hline $\mathrm{CMCF}$ & 51.9 & 51.3 & 51.3 & 5.8 \\
\hline EU & 42.0 & 28.4 & 28.4 & 3.2 \\
\hline $\mathrm{CDB}$ & 60.9 & 42.0 & 42.0 & 4.8 \\
\hline OPEC Fund & 18.2 & 16.1 & 16.1 & 1.8 \\
\hline IFAD & 4.1 & 2.9 & 2.9 & 0.3 \\
\hline Bilateral and commercial & 492.2 & 413.9 & 310.2 & 35.3 \\
\hline Paris Club 3/ & 295.5 & 224.1 & 223.8 & 25.5 \\
\hline Pre-cutoff & 261.9 & 197.4 & 197.2 & 22.4 \\
\hline ODA & 0.0 & 0.0 & 0.0 & 0.0 \\
\hline Non-ODA & 261.9 & 197.4 & 197.2 & 22.4 \\
\hline Post-cutoff & 33.5 & 26.7 & 26.7 & 3.0 \\
\hline ODA & 33.5 & 26.7 & 26.7 & 3.0 \\
\hline Non-ODA & 0.0 & 0.0 & 0.0 & 0.0 \\
\hline Canada & 1.4 & 1.3 & 1.3 & 0.1 \\
\hline Denmark & 1.1 & 1.2 & 1.0 & 0.1 \\
\hline France & 1.2 & 1.1 & 1.1 & 0.1 \\
\hline Germany & 14.5 & 8.7 & 8.7 & 1.0 \\
\hline Japan & 0.7 & 0.8 & 0.7 & 0.1 \\
\hline Netherlands & 4.6 & 4.4 & 4.4 & 0.5 \\
\hline Russian Federation & 3.9 & 3.4 & 3.4 & 0.4 \\
\hline Trinidad and Tobago & 176.9 & 125.1 & 125.1 & 14.2 \\
\hline United Kingdom & 53.9 & 47.6 & 47.6 & 5.4 \\
\hline United States & 37.2 & 30.5 & 30.5 & 3.5 \\
\hline Other official bilateral & 152.6 & 146.8 & 43.0 & 4.9 \\
\hline Pre-cutoff & 152.0 & 146.3 & 42.5 & 4.8 \\
\hline ODA & 54.9 & 48.8 & 21.8 & 2.5 \\
\hline Non-ODA & 97.2 & 97.5 & 20.6 & 2.3 \\
\hline Post-cutoff & 0.6 & 0.5 & 0.5 & 0.1 \\
\hline ODA & 0.6 & 0.5 & 0.5 & 0.1 \\
\hline Non-ODA & 0.0 & 0.0 & 0.0 & 0.0 \\
\hline Argentina & 10.1 & 10.1 & 2.1 & 0.2 \\
\hline Brazil & 0.0 & 0.0 & 0.0 & 0.0 \\
\hline Bulgaria & 1.0 & 1.0 & 0.2 & 0.0 \\
\hline China & 36.4 & 30.3 & 13.9 & 1.6 \\
\hline Cuba & 1.3 & 1.3 & 0.2 & 0.0 \\
\hline DPRK & 0.0 & 0.0 & 0.1 & 0.0 \\
\hline India & 0.6 & 0.5 & 0.5 & 0.1 \\
\hline Kuwait & 46.7 & 47.0 & 9.1 & 1.0 \\
\hline Libya & 36.1 & 36.1 & 7.8 & 0.9 \\
\hline United Arab Emirates & 6.0 & 6.0 & 4.8 & 0.6 \\
\hline Venezuela & 13.3 & 13.3 & 3.9 & 0.4 \\
\hline Former Republic of Yugoslavia & 1.2 & 1.2 & 0.2 & 0.0 \\
\hline Commercial creditors & 44.1 & 43.0 & 43.3 & 4.9 \\
\hline Canada & 0.0 & 0.0 & 0.0 & 0.0 \\
\hline India & 0.2 & 0.2 & 0.2 & 0.0 \\
\hline Norway & 2.2 & 2.2 & 2.2 & 0.2 \\
\hline United Kingdom & 37.5 & 36.5 & 36.5 & 4.2 \\
\hline United States & 0.6 & 0.6 & 0.6 & 0.1 \\
\hline EPDS & 3.5 & 3.5 & 3.9 & 0.4 \\
\hline Bonds & 0.0 & 0.0 & 0.0 & 0.0 \\
\hline
\end{tabular}

Sources: Guyanese authorities; and staff estimates.

1/ Figures are based on data at end-2002 and refers to public and publicly guaranteed external debt only.

2/ Reflects the external debt situation as of end-2002, and includes the 1996 Paris Club stock-of-debt operation on Naples terms and the 1999 Paris Club stock-of-debt operation on Lyon terms under the original HIPC initiative from the Paris Club creditors.

3/ Reflects full delivery of assistance under the original HIPC initiative. 
Table 7. Guyana: Comparison of Discount Rate and Exchange Rate Assumptions at End-1998 and End-2002

\begin{tabular}{|c|c|c|c|c|}
\hline \multirow[b]{2}{*}{ Currency } & \multicolumn{2}{|c|}{$\begin{array}{l}\text { Discount Rates } 1 / 2 / \\
\text { (In percent per annum) }\end{array}$} & \multicolumn{2}{|c|}{$\begin{array}{c}\text { Exchange Rates 2/ } \\
\text { (Currency per U.S. dollar) }\end{array}$} \\
\hline & At decision point & At completion point & At decision point & At completion point \\
\hline United States Dollar & 6.23 & 5.12 & 1.00 & 1.00 \\
\hline Special Drawing Rights & 5.25 & 4.82 & 0.71 & 0.74 \\
\hline United Arab Emirates Dirham & 5.25 & 4.82 & 3.67 & 3.67 \\
\hline Canadian dollar & 6.25 & 5.88 & 1.53 & 1.58 \\
\hline Chinese Yuan & 5.25 & 4.82 & 8.28 & 8.28 \\
\hline Deutsche Mark & 5.16 & 5.55 & 1.67 & 1.87 \\
\hline Danish Kroner & 5.64 & 5.78 & 6.39 & 7.08 \\
\hline Guyanese Dollar & 6.23 & 5.55 & 154.10 & 162.25 \\
\hline European Euro & 5.00 & 5.55 & 0.84 & 0.95 \\
\hline Great Britain Sterling & 6.81 & 5.84 & 0.60 & 0.62 \\
\hline Indian Rupee & 5.25 & 4.82 & 39.28 & 48.03 \\
\hline Italian Lira & 5.58 & 5.55 & 1653.10 & 2197.06 \\
\hline Japanese Yen & 2.22 & 1.75 & 115.60 & 119.90 \\
\hline Kuwaiti Dinar & 5.25 & 4.82 & 0.30 & 0.30 \\
\hline Netherland Guilders & 5.78 & 5.55 & 1.89 & 2.10 \\
\hline Saudi Arabian Rial & 5.25 & 4.82 & 3.75 & 3.75 \\
\hline Swedish Kroner & 5.66 & 6.11 & 8.06 & 8.83 \\
\hline Units of account (IDB) & 4.88 & 4.82 & 0.65 & 0.66 \\
\hline \multicolumn{5}{|l|}{ Memorandum item: } \\
\hline Paris Club cutoff date is Decen & 988 & & & \\
\hline
\end{tabular}

Sources: OECD; and IMF, International Financial Statistics.

1/ The discount rates used are the average commercial interest reference rates (CIRRs) for the respective currencies over the six-month period ending in December 2002 for the completion point and in December 1998 for the decision point.

2/ For all currencies for which the CIRRs are not available, the SDR discount rate is used as a proxy. 


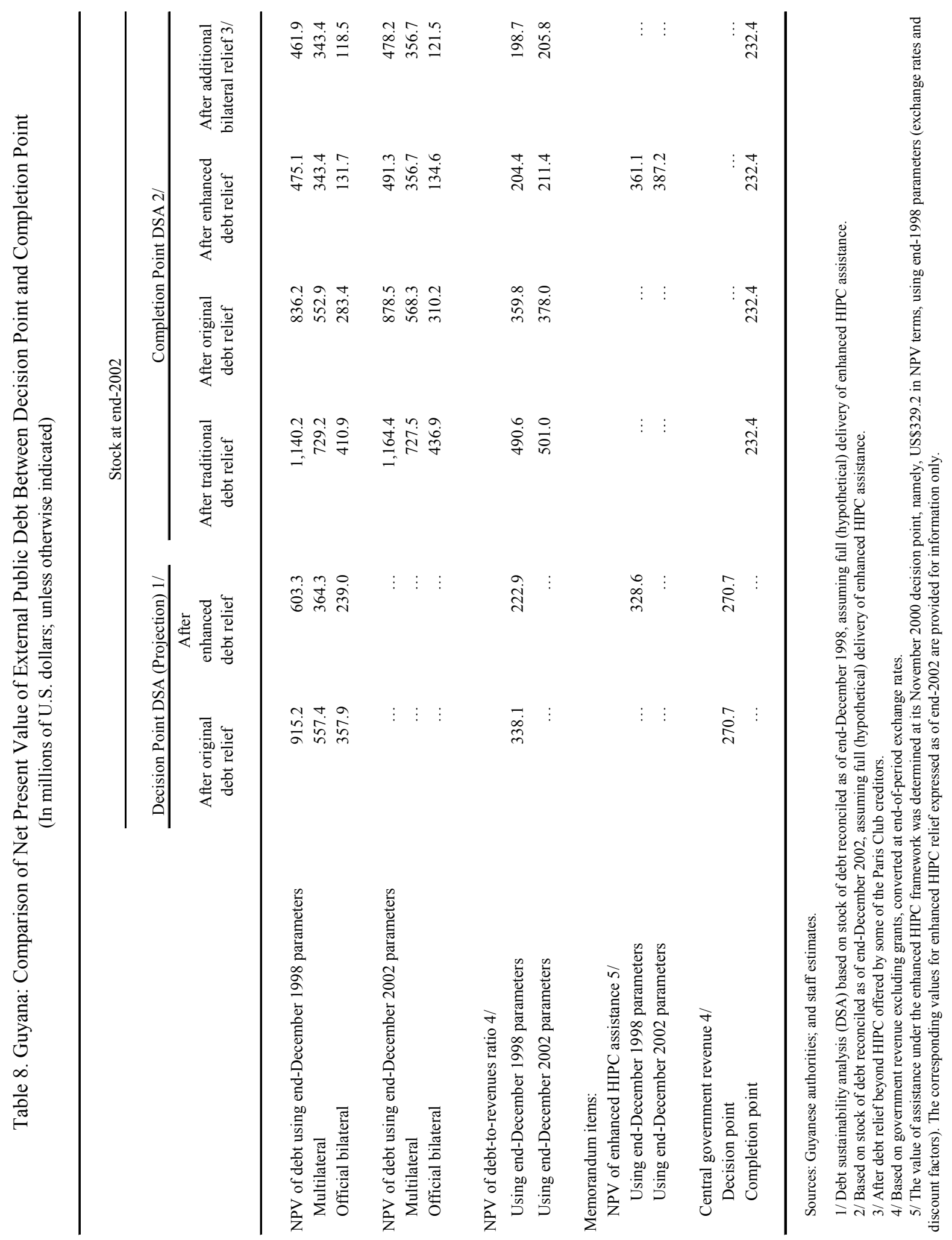


源

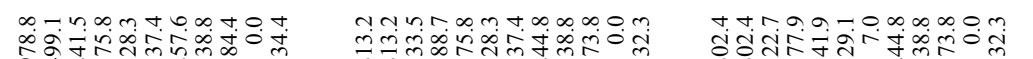

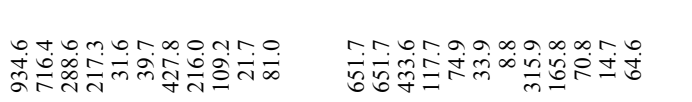

ํํ의

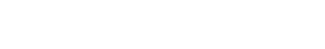

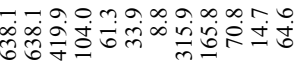

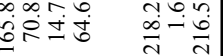

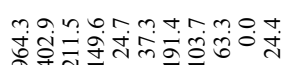

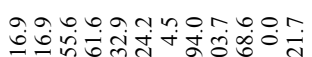

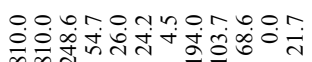

茟过

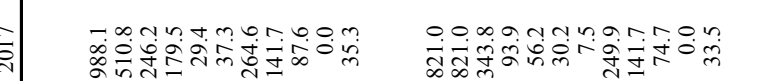

$\sin$

굴

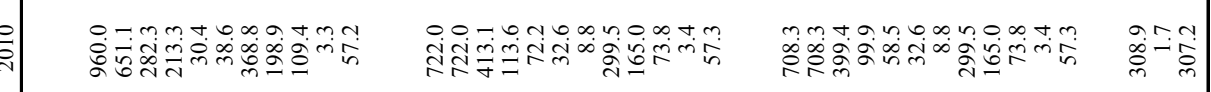

กิ

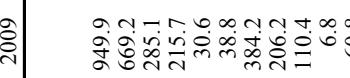

$\stackrel{\infty}{0}$

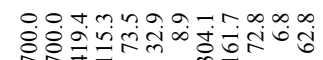

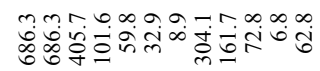

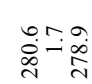

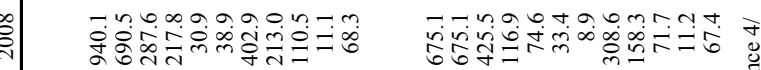

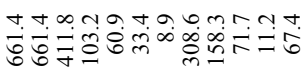

辛辛辛

率

: thn 焉

苟

造

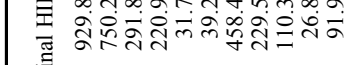

范 亳

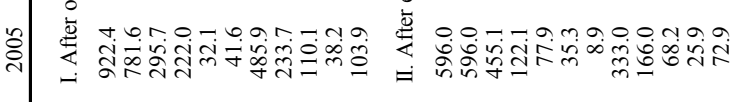
दूँ

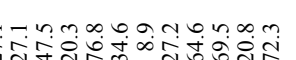

8. thenthonomom

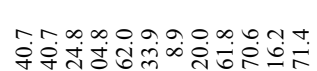

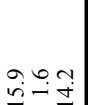

$\frac{4}{\sin }-\frac{4}{4}$

完

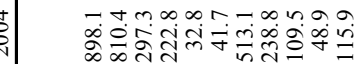

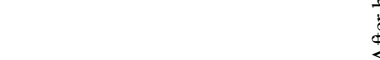

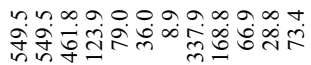
unt

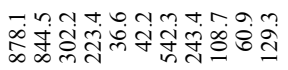

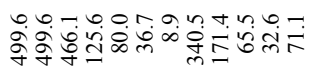

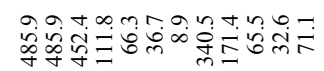

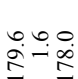
密

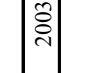

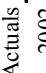

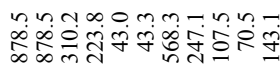

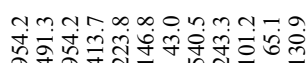

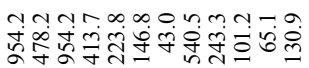

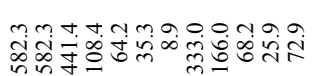

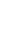

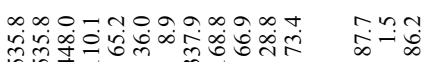

促

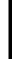

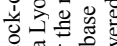

of

过记

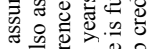

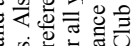

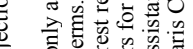

年

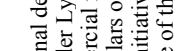

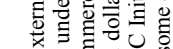

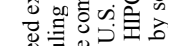
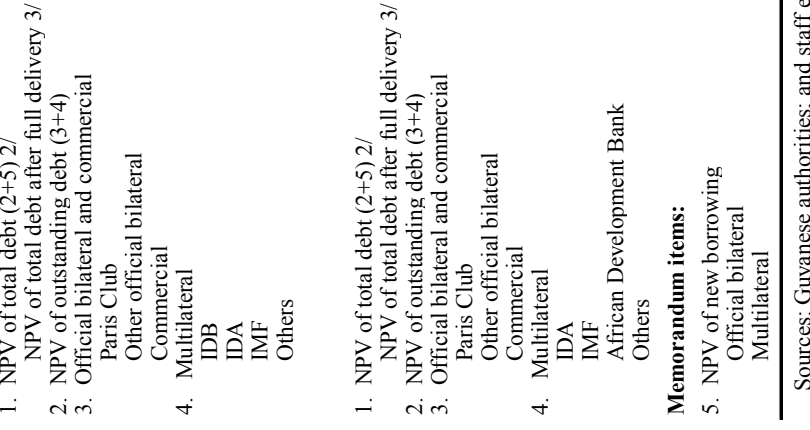

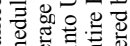

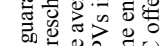

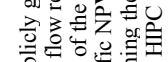

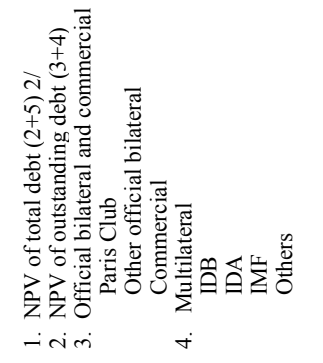

同产

궁

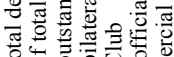

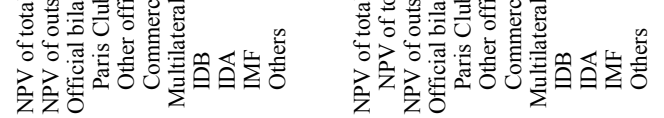

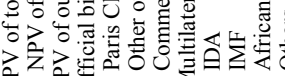

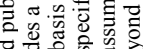

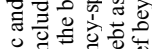

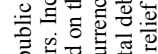

डै 녕

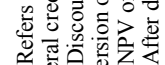

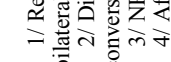


Table 10. Guyana: External Debt Service After Full Implementation of Debt-Relief Mechanisms, 2003-2022 (In millions of U.S. dollars; unless otherwise indicated)

\begin{tabular}{|c|c|c|c|c|c|c|c|c|c|c|c|c|c|}
\hline & 2003 & 2004 & 2005 & 2006 & 2007 & 2008 & 2009 & 2010 & 2020 & 2021 & 2022 & $2003-12$ & $2013-22$ \\
\hline Total debt service $1 /$ & 100.1 & 102.9 & 100.2 & 98.9 & 97.8 & 96.3 & 85.3 & 83.8 & 63.9 & 65.4 & 61.7 & 95.2 & 86.8 \\
\hline After traditional debt-relief mechanisms 2/ & 99.4 & 101.4 & 97.9 & 96.0 & 94.3 & 92.2 & 79.8 & 73.8 & 39.8 & 39.4 & 33.8 & 88.5 & 65.3 \\
\hline Multilateral & 73.1 & 73.8 & 69.6 & 67.0 & 64.1 & 61.2 & 47.7 & 40.5 & 32.5 & 31.7 & 30.4 & 57.6 & 34.7 \\
\hline IDB & 21.3 & 21.9 & 22.1 & 20.5 & 23.1 & 24.3 & 21.5 & 21.6 & 16.8 & 16.3 & 15.2 & 21.9 & 18.6 \\
\hline IDA & 5.7 & 6.1 & 6.6 & 6.9 & 7.1 & 7.0 & 7.2 & 8.4 & 10.7 & 10.6 & 10.4 & 7.4 & 10.5 \\
\hline IMF & 17.8 & 18.9 & 16.4 & 15.8 & 10.8 & 8.6 & 5.0 & 3.8 & 0.0 & 0.0 & 0.0 & 10.1 & 0.0 \\
\hline Others & 28.3 & 26.9 & 24.6 & 23.7 & 23.1 & 21.3 & 14.0 & 6.7 & 5.0 & 4.9 & 4.8 & 18.2 & 5.6 \\
\hline Official bilateral & 26.3 & 27.5 & 28.3 & 29.0 & 30.1 & 31.0 & 32.1 & 33.3 & 7.3 & 7.7 & 3.4 & 30.8 & 30.6 \\
\hline Paris Club & 23.3 & 24.2 & 25.1 & 26.0 & 27.1 & 28.1 & 29.2 & 30.4 & 2.3 & 2.2 & 2.2 & 27.8 & 26.9 \\
\hline Of which: $O D A$ & 2.2 & 2.3 & 2.3 & 2.2 & 2.2 & 2.1 & 2.1 & 2.1 & 1.7 & 1.6 & 1.6 & 2.1 & 1.8 \\
\hline Other official bilateral and commercial & 3.1 & 3.3 & 3.2 & 3.0 & 3.1 & 2.9 & 3.0 & 2.9 & 5.0 & 5.4 & 1.1 & 3.0 & 3.8 \\
\hline Of which: $O D A$ & 1.3 & 1.6 & 1.6 & 1.4 & 1.4 & 1.1 & 1.1 & 0.9 & 1.0 & 1.1 & 1.1 & 1.2 & 0.8 \\
\hline Total debt service $1 /$ & 75.9 & 75.9 & 70.1 & 69.5 & 69.2 & 68.7 & 59.7 & 59.9 & 66.5 & 68.9 & 67.1 & 68.4 & 67.0 \\
\hline After original HIPC assistance 3/ & 75.3 & 74.3 & 67.8 & 66.5 & 65.6 & 64.6 & 54.1 & 50.0 & 42.4 & 42.8 & 39.3 & 61.7 & 45.5 \\
\hline Multilateral & 54.5 & 56.4 & 52.9 & 51.8 & 50.4 & 49.4 & 38.7 & 34.4 & 26.2 & 25.8 & 25.5 & 45.5 & 28.1 \\
\hline IDB & 15.9 & 16.6 & 16.9 & 15.8 & 18.8 & 20.0 & 17.3 & 17.5 & 13.7 & 13.4 & 13.2 & 17.4 & 15.2 \\
\hline IDA & 4.1 & 4.4 & 4.7 & 5.1 & 5.2 & 5.2 & 5.4 & 6.4 & 8.7 & 8.6 & 8.6 & 5.5 & 8.4 \\
\hline IMF & 13.3 & 15.2 & 13.3 & 13.4 & 9.4 & 8.6 & 5.0 & 3.8 & 0.0 & 0.0 & 0.0 & 8.6 & 0.0 \\
\hline Others & 21.3 & 20.1 & 18.0 & 17.5 & 17.0 & 15.5 & 11.1 & 6.8 & 3.8 & 3.7 & 3.7 & 14.1 & 4.5 \\
\hline Official bilateral & 20.8 & 18.0 & 14.9 & 14.8 & 15.1 & 15.2 & 15.4 & 15.5 & 16.2 & 17.0 & 13.8 & 16.2 & 17.3 \\
\hline Paris Club & 12.3 & 12.4 & 12.5 & 12.8 & 13.1 & 13.4 & 13.6 & 13.9 & 13.7 & 14.3 & 11.8 & 13.3 & 15.3 \\
\hline Of which: ODA & 2.2 & 2.3 & 2.3 & 2.2 & 2.2 & 2.1 & 2.1 & 2.1 & 1.7 & 1.6 & 1.6 & 2.1 & 1.8 \\
\hline Other official bilateral and commercial & 8.5 & 5.6 & 2.4 & 2.0 & 2.1 & 1.8 & 1.9 & 1.7 & 2.5 & 2.7 & 2.0 & 2.9 & 2.0 \\
\hline Of which: ODA & 1.3 & 1.6 & 1.6 & 1.4 & 1.4 & 1.1 & 1.1 & 0.9 & 1.0 & 1.0 & 1.1 & 1.2 & 0.8 \\
\hline Total debt service $1 /$ & 52.3 & 33.6 & 32.0 & 33.3 & 35.3 & 38.8 & 32.9 & 37.4 & 55.7 & 61.5 & 64.0 & 38.5 & 53.2 \\
\hline After enhanced HIPC assistance & 51.6 & 32.0 & 29.6 & 30.4 & 31.7 & 34.7 & 27.4 & 27.4 & 31.6 & 35.4 & 36.1 & 31.7 & 31.7 \\
\hline Multilateral & 35.7 & 24.3 & 22.0 & 22.8 & 24.2 & 27.5 & 20.2 & 20.3 & 21.7 & 25.0 & 25.1 & 23.5 & 22.9 \\
\hline IDB & 11.5 & 11.0 & 11.1 & 9.6 & 10.9 & 11.5 & 4.4 & 4.7 & 13.7 & 13.4 & 13.2 & 8.4 & 14.0 \\
\hline IDA & 1.7 & 1.9 & 2.0 & 2.2 & 2.3 & 2.3 & 2.5 & 2.9 & 4.1 & 7.8 & 8.6 & 2.5 & 4.7 \\
\hline IMF & 6.6 & 5.3 & 4.4 & 6.3 & 5.5 & 5.8 & 5.0 & 3.8 & 0.0 & 0.0 & 0.0 & 4.6 & 0.0 \\
\hline Others & 15.9 & 6.1 & 4.6 & 4.6 & 5.4 & 7.9 & 8.3 & 8.9 & 3.9 & 3.8 & 3.2 & 7.9 & 4.2 \\
\hline Official bilateral & 15.9 & 7.7 & 7.7 & 7.6 & 7.6 & 7.2 & 7.2 & 7.1 & 9.9 & 10.4 & 11.0 & 8.3 & 8.8 \\
\hline Paris Club & 12.2 & 5.3 & 5.2 & 5.2 & 5.1 & 5.1 & 5.1 & 5.2 & 7.2 & 7.5 & 7.9 & 5.9 & 6.6 \\
\hline Of which: ODA & 2.2 & 2.3 & 2.3 & 2.2 & 2.2 & 2.1 & 2.1 & 2.1 & 1.7 & 1.6 & 1.6 & 2.1 & 1.8 \\
\hline Other official bilateral and commercial & 3.7 & 2.4 & 2.4 & 2.4 & 2.4 & 2.1 & 2.1 & 2.0 & 2.7 & 2.9 & 3.1 & 2.4 & 2.2 \\
\hline Of which: ODA & 3.5 & 1.3 & 1.3 & 1.3 & 1.3 & 1.0 & 1.0 & 0.7 & 0.3 & 0.4 & 0.4 & 1.3 & 0.2 \\
\hline Total debt service & 52.3 & 32.8 & 31.2 & 32.5 & 34.5 & 38.0 & 32.1 & 36.6 & 54.2 & 59.9 & 62.3 & 37.7 & 51.9 \\
\hline After bilateral debt relief beyond HIPC 4/ & 51.6 & 31.3 & 28.9 & 29.6 & 31.0 & 33.9 & 26.6 & 26.6 & 30.1 & 33.9 & 34.4 & 31.0 & 30.4 \\
\hline Multilateral & 35.7 & 24.3 & 22.0 & 22.8 & 24.2 & 27.5 & 20.2 & 20.3 & 21.7 & 25.0 & 25.1 & 23.5 & 22.9 \\
\hline Official bilateral & 15.9 & 6.9 & 6.9 & 6.8 & 6.8 & 6.5 & 6.4 & 6.3 & 8.4 & 8.8 & 9.3 & 7.6 & 7.5 \\
\hline Paris Club & 12.2 & 4.5 & 4.5 & 4.4 & 4.4 & 4.3 & 4.3 & 4.4 & 5.7 & 5.9 & 6.2 & 5.2 & 5.3 \\
\hline Of which: ODA & 2.2 & 2.3 & 2.3 & 2.2 & 2.2 & 2.1 & 2.1 & 2.1 & 1.7 & 1.6 & 1.6 & 2.1 & 1.8 \\
\hline Other official bilateral and commercial & 3.7 & 2.4 & 2.4 & 2.4 & 2.4 & 2.1 & 2.1 & 2.0 & 2.7 & 2.9 & 3.1 & 2.4 & 2.2 \\
\hline Of which: ODA & 3.5 & 1.3 & 1.3 & 1.3 & 1.3 & 1.0 & 1.0 & 0.7 & 0.3 & 0.4 & 0.4 & 1.3 & 0.2 \\
\hline \multicolumn{14}{|l|}{ Memorandum items: } \\
\hline Debt service of new debt & 0.6 & 1.5 & 2.3 & 2.9 & 3.6 & 4.1 & 5.5 & 10.0 & 24.1 & 26.0 & 27.9 & 6.7 & 21.5 \\
\hline Multilateral & 0.6 & 1.5 & 2.3 & 2.9 & 3.5 & 4.1 & 5.5 & 9.9 & 23.9 & 25.8 & 27.7 & 6.7 & 21.3 \\
\hline Official bilateral & 0.0 & 0.1 & 0.1 & 0.1 & 0.1 & 0.1 & 0.1 & 0.1 & 0.2 & 0.2 & 0.2 & 0.1 & 0.1 \\
\hline \multicolumn{14}{|l|}{ Nominal HIPC relief } \\
\hline Under the original HIPC initiative & 24.2 & 27.1 & 30.2 & 29.4 & 28.7 & 27.6 & 25.7 & 23.9 & -2.6 & -3.4 & -5.5 & 26.8 & 19.9 \\
\hline Under the enhanced HIPC initiative & 23.7 & 42.3 & 38.1 & 36.2 & 33.9 & 29.9 & 26.8 & 22.5 & 10.8 & 7.4 & 3.2 & 29.9 & 13.8 \\
\hline
\end{tabular}

Sources: Guyanese authorities; and staff estimates.

1/ Includes debt service on new debt.

2/ Assumes a stock-of-debt operation on Naples terms (67 percent NPV reduction) at the end of 1996, and at least comparable action by other bilateral creditors

3 / Includes debt relief from original HIPC Initiative.

4/ After debt relief beyond HIPC offered by some of the Paris Club creditors. 


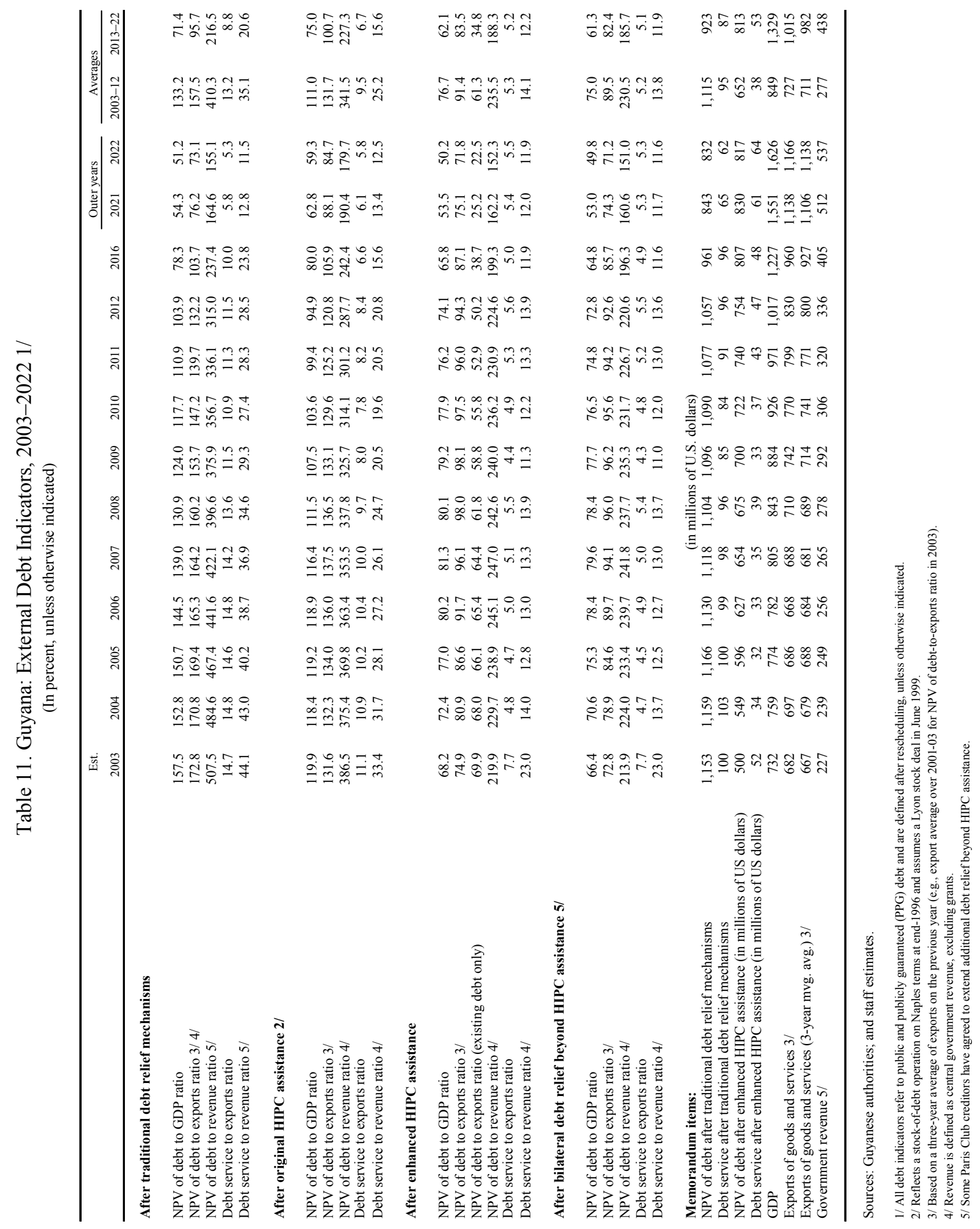




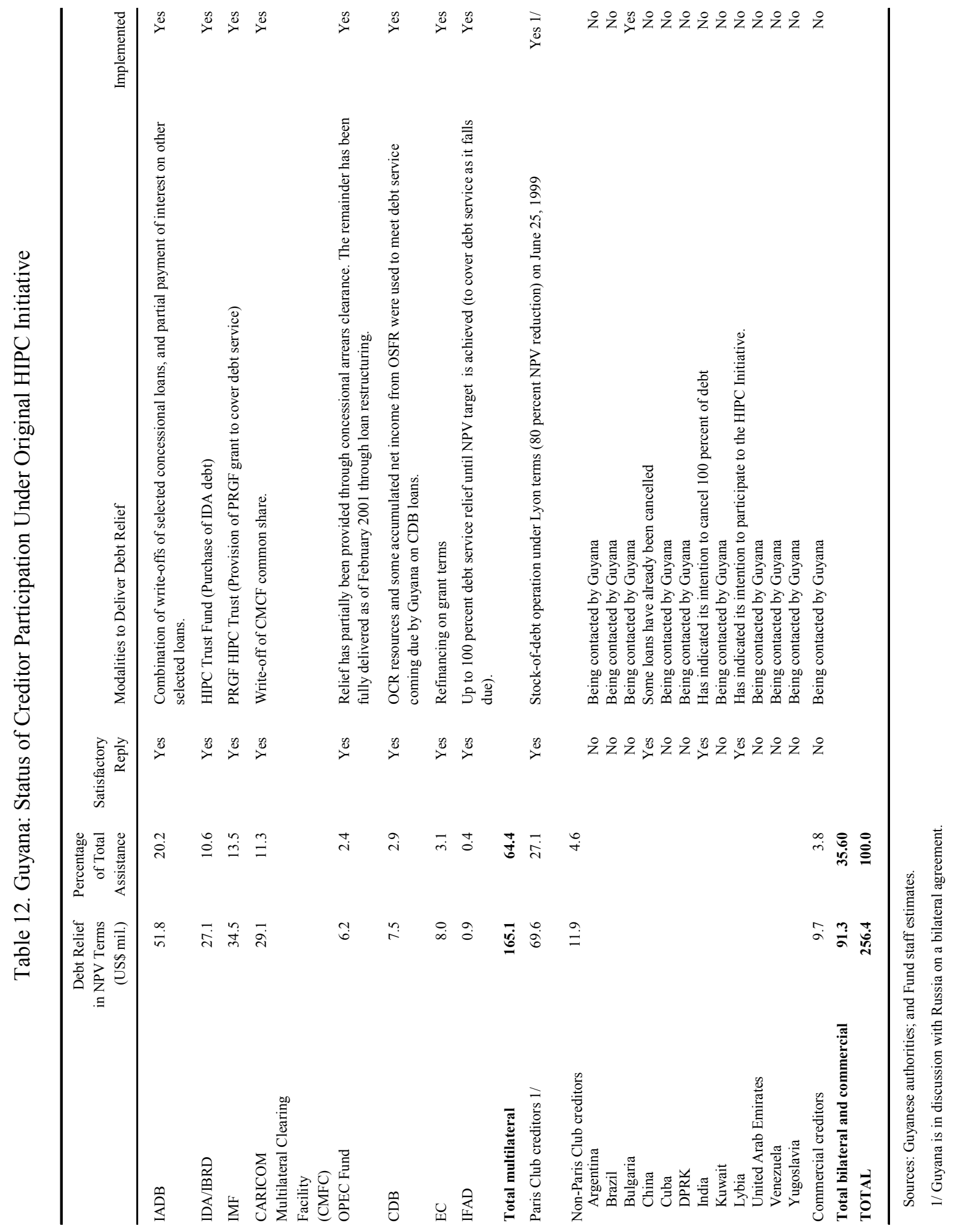




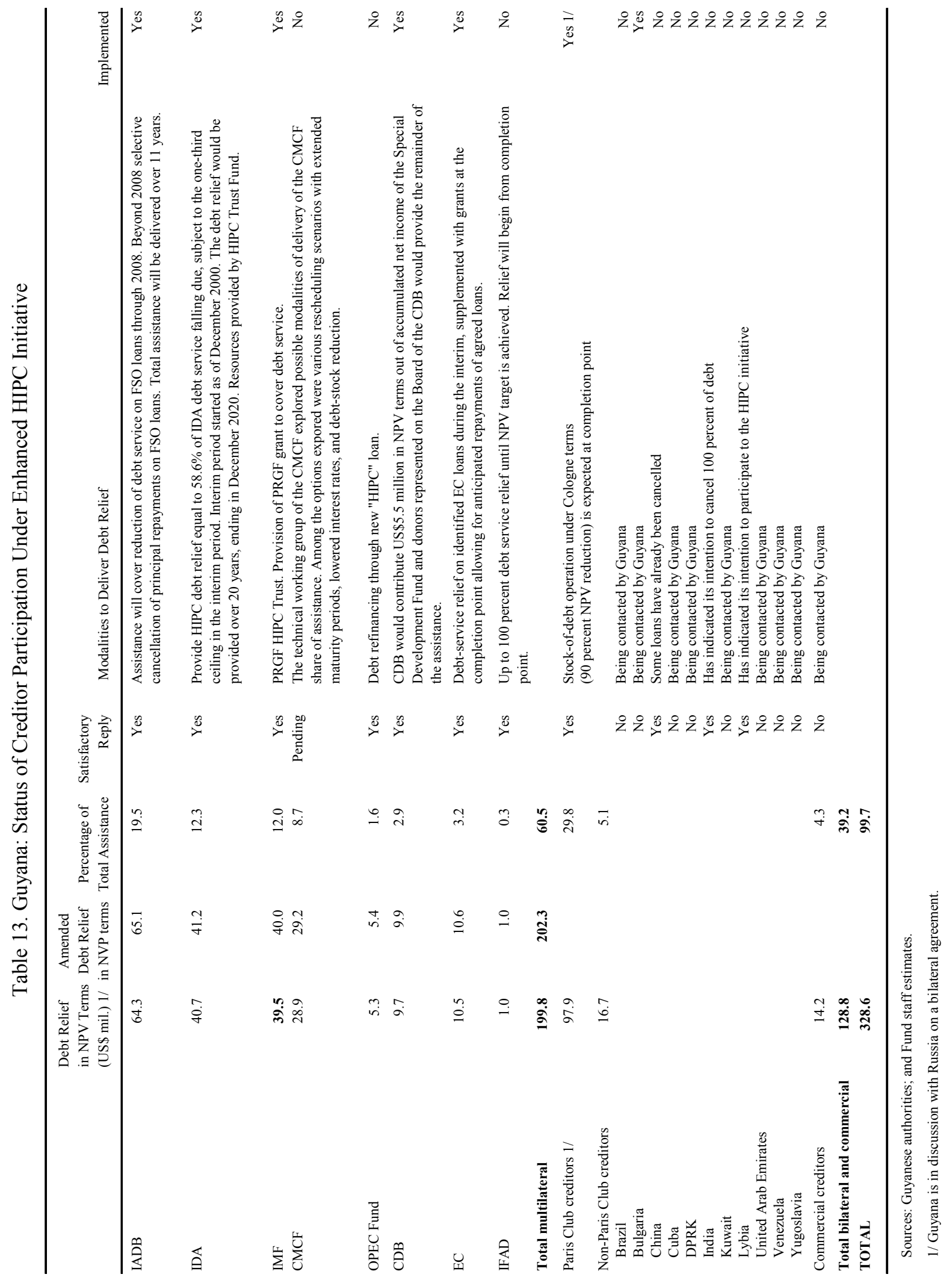




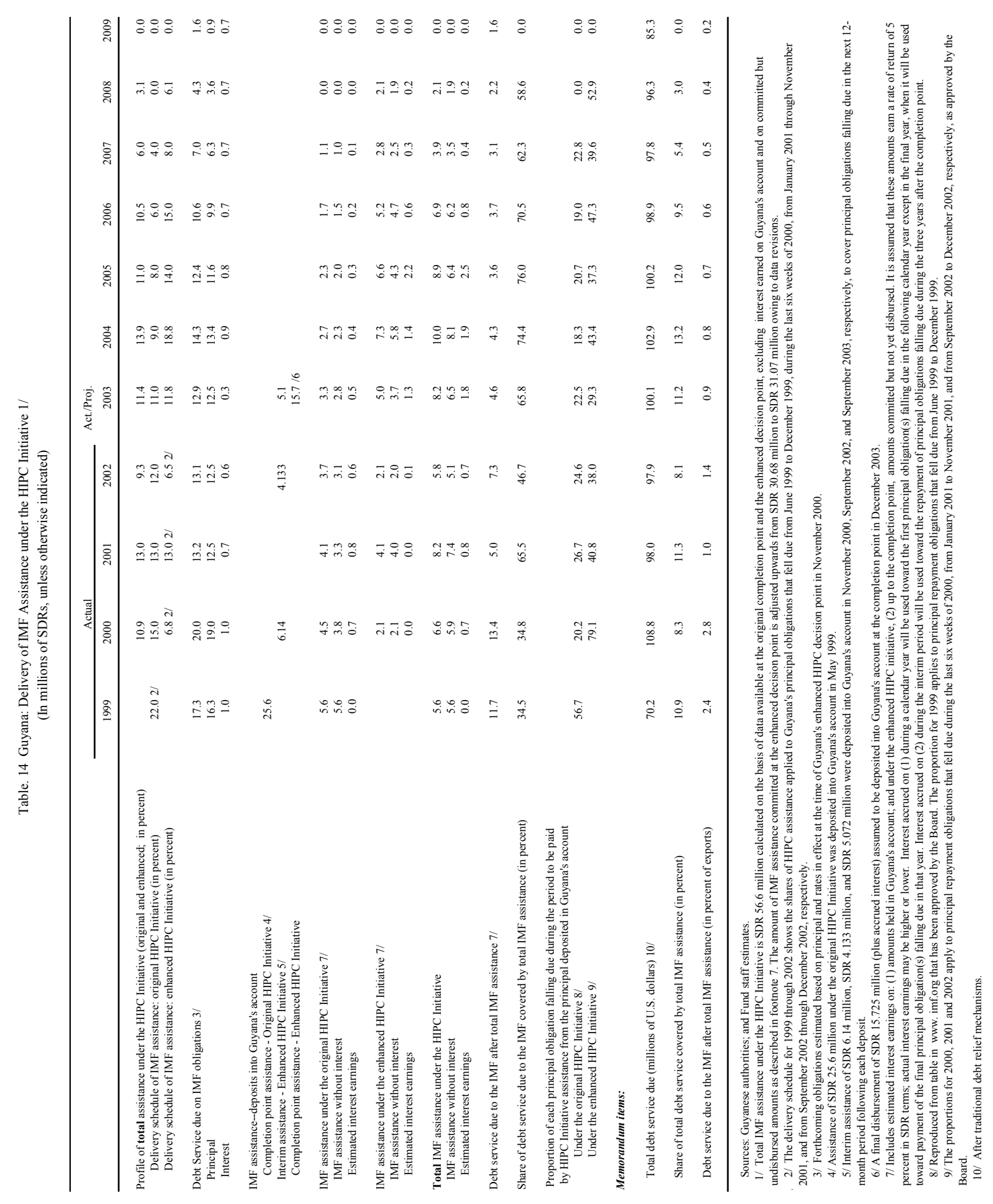




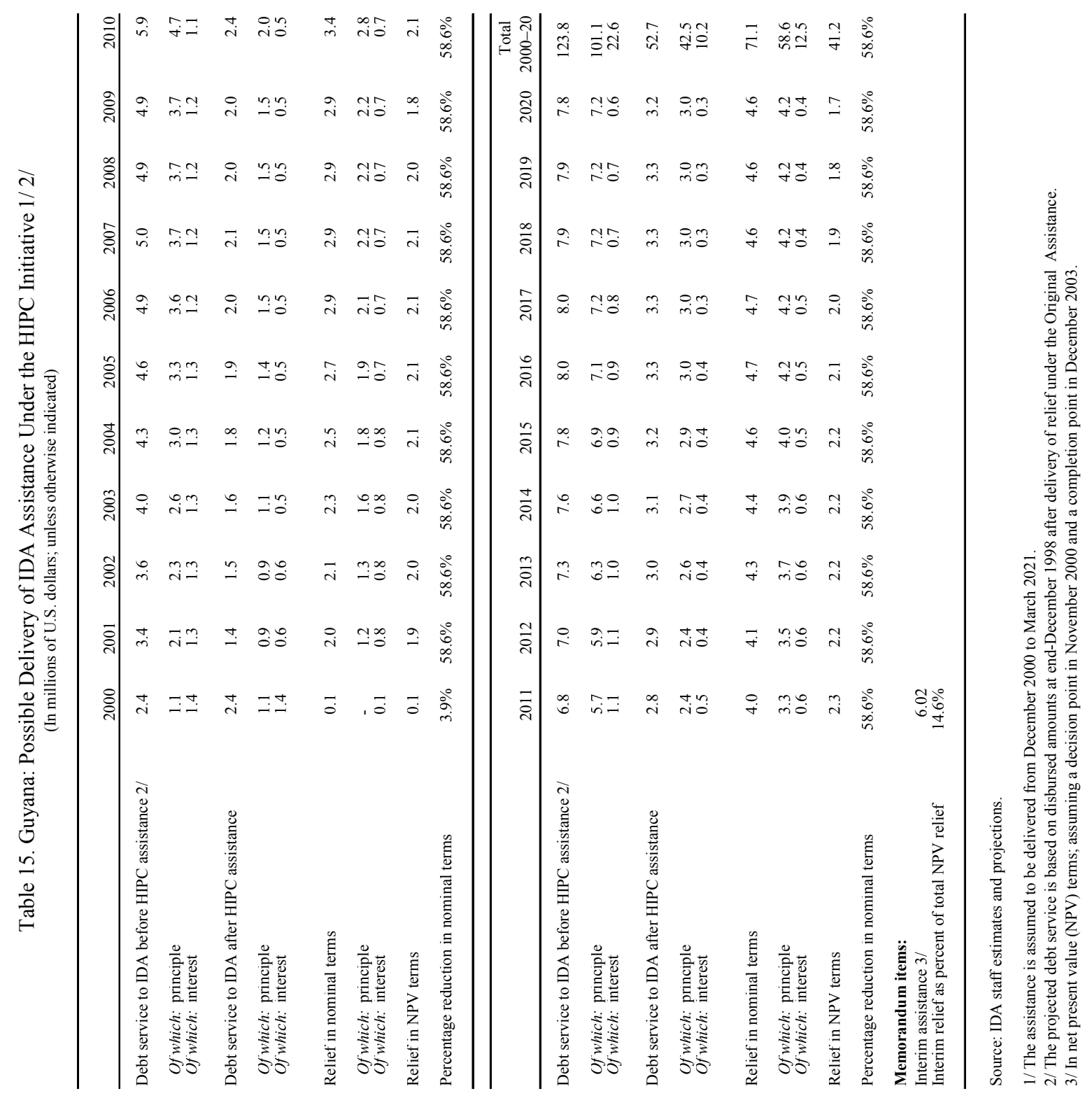




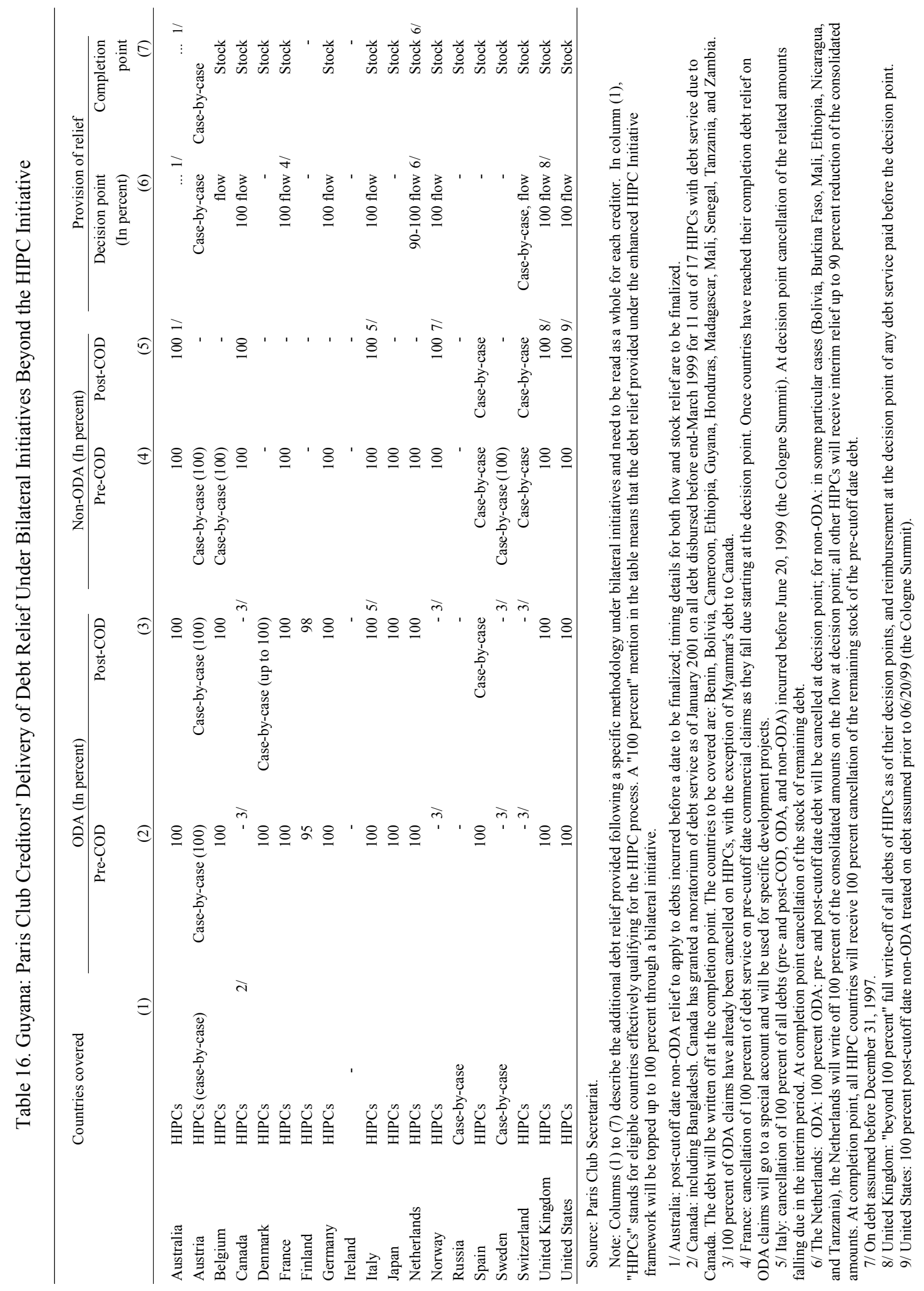


Table 17. Guyana: HIPC Initiative: Status of Country Cases Considered Under the Initiative, July 31, 2003

\begin{tabular}{|c|c|c|c|c|c|c|c|c|c|c|c|}
\hline \multirow[b]{3}{*}{ Country } & \multirow{3}{*}{$\begin{array}{r}\text { Decision } \\
\text { Point }\end{array}$} & \multirow{3}{*}{$\begin{array}{r}\text { Completion } \\
\text { Point }\end{array}$} & \multicolumn{2}{|c|}{$\begin{array}{c}\text { Target } \\
\text { NPV of Debt-to- }\end{array}$} & \multirow{2}{*}{\multicolumn{4}{|c|}{$\begin{array}{c}\text { Assistance Levels 1/ } \\
\text { (In millions of U.S. dollars, present value) }\end{array}$}} & & \multirow{3}{*}{$\begin{array}{r}\text { Percentage } \\
\text { Reduction } \\
\text { in NPV of } \\
\text { Debt } 2 /\end{array}$} & \multirow{3}{*}{$\begin{array}{r}\text { Estimated Total } \\
\text { Nominal Debt } \\
\text { Service Relief } \\
\text { (In millions of } \\
\text { U.S. dollars) }\end{array}$} \\
\hline & & & & Gov. & & & & & & & \\
\hline & & & \multicolumn{2}{|c|}{ (In percent) } & Total & Bilateral & $\begin{array}{l}\text { Multi- } \\
\text { lateral }\end{array}$ & IMF & $\begin{array}{r}\text { World } \\
\text { Bank }\end{array}$ & & \\
\hline \multicolumn{12}{|c|}{ Completion point reached under enhanced framework } \\
\hline Benin & Jul. 00 & Mar. 03 & 150 & & 265 & 77 & 189 & 24 & 84 & 31 & 460 \\
\hline Bolivia & & & & & 1,302 & 425 & 876 & 84 & 194 & & 2,060 \\
\hline Original framework & Sep. 97 & Sep. 98 & 225 & & 448 & 157 & 291 & 29 & 54 & 14 & 760 \\
\hline Enhanced framework & Feb. 00 & Jun. 01 & 150 & & 854 & 268 & 585 & 55 & 140 & 30 & 1,300 \\
\hline Burkina Faso & & & & & 553 & 83 & 469 & 57 & 231 & & 930 \\
\hline Original framework & Sep. 97 & Jul. 00 & 205 & & 229 & 32 & 196 & 22 & 91 & 27 & 400 \\
\hline Enhanced framework & Jul. 00 & Apr. 02 & 150 & & 195 & 35 & 161 & 22 & 79 & 30 & 300 \\
\hline Topping-up & $\ldots$ & Apr. 02 & 150 & & 129 & 16 & 112 & 14 & 61 & 24 & 230 \\
\hline Mali & & & & & 539 & 169 & 370 & 59 & 185 & & 895 \\
\hline Original framework & Sep. 98 & Sep. 00 & 200 & & 121 & 37 & 84 & 14 & 43 & 9 & 220 \\
\hline Enhanced framework & Sep. 00 & Mar. 03 & 150 & & 417 & 132 & 285 & 45 & 143 & 29 & 675 \\
\hline Mauritania & Feb. 00 & Jun. 02 & 137 & 250 & 622 & 261 & 361 & 47 & 100 & 50 & 1,100 \\
\hline Mozambique & & & & & 2,023 & 1,270 & 753 & 143 & 443 & & 4,300 \\
\hline Original framework & Apr. 98 & Jun. 99 & 200 & & 1,717 & 1,076 & 641 & 125 & 381 & 63 & 3,700 \\
\hline Enhanced framework & Apr. 00 & Sep. 01 & 150 & & 306 & 194 & 112 & 18 & 62 & 27 & 600 \\
\hline Tanzania & Apr. 00 & Nov. 01 & 150 & & 2,026 & 1,006 & 1,020 & 120 & 695 & 54 & 3,000 \\
\hline Uganda & & & & & 1,003 & 183 & 820 & 160 & 517 & & 1,950 \\
\hline Original framework & Apr. 97 & Apr. 98 & 202 & & 347 & 73 & 274 & 69 & 160 & 20 & 650 \\
\hline Enhanced framework & Feb. 00 & May 00 & 150 & & 656 & 110 & 546 & 91 & 357 & 37 & 1,300 \\
\hline \multicolumn{12}{|c|}{ Decision point reached under enhanced framework } \\
\hline Cameroon & Oct. 00 & Floating & 150 & & 1,260 & 874 & 324 & 37 & 179 & 27 & 2,000 \\
\hline Chad & May. 01 & Floating & 150 & & 170 & 35 & 134 & 18 & 68 & 30 & 260 \\
\hline Congo, Democratic Rep. of & Jul. 03 & Floating & 150 & & 6,311 & 3,837 & 2,474 & 472 & 831 & 80 & 10,389 \\
\hline Ethiopia & Nov. 01 & Floating & 150 & & 1,275 & 482 & 763 & 34 & 463 & 47 & 1,930 \\
\hline Gambia, The & Dec. 00 & Floating & 150 & & 67 & 17 & 49 & 2 & 22 & 27 & 90 \\
\hline Ghana & Feb. 02 & Floating & 69 & 250 & 2,186 & 1,084 & 1,102 & 112 & 781 & 56 & 3,700 \\
\hline Guinea & Dec. 00 & Floating & 150 & & 545 & 215 & 328 & 31 & 152 & 32 & 800 \\
\hline Guinea-Bissau & Dec. 00 & Floating & 150 & & 416 & 212 & 204 & 12 & 93 & 85 & 790 \\
\hline Guyana & & & & & 585 & 220 & 365 & 74 & 68 & & 1,031 \\
\hline Original framework & Dec. 97 & May 99 & 107 & 280 & 256 & 91 & 165 & 35 & 27 & 24 & 440 \\
\hline Enhanced framework & Nov. 00 & Floating & 150 & 250 & 329 & 129 & 200 & 40 & 41 & 40 & 591 \\
\hline Honduras & Jul. 00 & Floating & 110 & 250 & 556 & 215 & 340 & 30 & 98 & 18 & 900 \\
\hline Madagascar & Dec. 00 & Floating & 150 & & 814 & 457 & 357 & 22 & 252 & 40 & 1,500 \\
\hline Malawi & Dec. 00 & Floating & 150 & & 643 & 163 & 480 & 30 & 331 & 44 & 1,000 \\
\hline Nicaragua & Dec. 00 & Floating & 150 & & 3,267 & 2,145 & 1,123 & 82 & 189 & 72 & 4,500 \\
\hline Niger & Dec. 00 & Floating & 150 & & 521 & 211 & 309 & 28 & 170 & 54 & 900 \\
\hline Rwanda & Dec. 00 & Floating & 150 & & 452 & 56 & 397 & 44 & 228 & 71 & 800 \\
\hline São Tomé and Príncipe & Dec. 00 & Floating & 150 & & 97 & 29 & 68 & - & 24 & 83 & 200 \\
\hline Senegal & Jun. 00 & Floating & 133 & 250 & 488 & 193 & 259 & 45 & 124 & 19 & 850 \\
\hline Sierra Leone & Mar. 02 & Floating & 150 & & 600 & 205 & 354 & 123 & 122 & 80 & 950 \\
\hline Zambia & Dec. 00 & Floating & 150 & & 2,499 & 1,168 & 1,331 & 602 & 493 & 63 & 3,850 \\
\hline \multicolumn{12}{|l|}{ Preliminary HIPC document issued } \\
\hline Côte d'Ivoire & Mar. 98 3/ & $\ldots$ & 141 & 280 & 345 & 163 & 182 & 23 & 91 & 64 & 800 \\
\hline Total assistance provided/committed & & & & & 31,428 & 15,456 & 15,801 & $2,5165 /$ & 7,228 & & 51,935 \\
\hline \multicolumn{12}{|l|}{ Preliminary HIPC document issued } \\
\hline Côte d'Ivoire 6/ & $\cdots$ & $\ldots$ & 91 & 250 & 2,569 & 1,027 & 918 & 166 & 438 & 37 & 3,900 \\
\hline
\end{tabular}

Sources: IMF and World Bank Board decisions, completion point documents, decision point documents, preliminary HIPC documents, and staff calculations

1/ Assistance levels are at countries' respective decision or completion points, as applicable.

2/ In percent of the net present value of debt at the decision or completion point (as applicable), after the full use of traditional debt-relief mechanisms.

3/ Côte d'Ivoire reached its decision point under the original framework in March 1998. The total amount of assistance committed thereunder was US\$345 million in NPV terms.

4/ Nonreschedulable debt to non-Paris Club official bilateral creditors and the London Club, which was already subject to a highly concessional restructuring, is

excluded from the NPVof debt at the completion point in the calculation of this ratio.

5/ Equivalent to SDR 1,796 million at an SDR/US\$ exchange rate of 0.7138, as of June 30, 2003.

6/ It is suggested that enhanced HIPC relief for Côte d'Ivoire overtakes the commitments made under the original HIPC framework. 


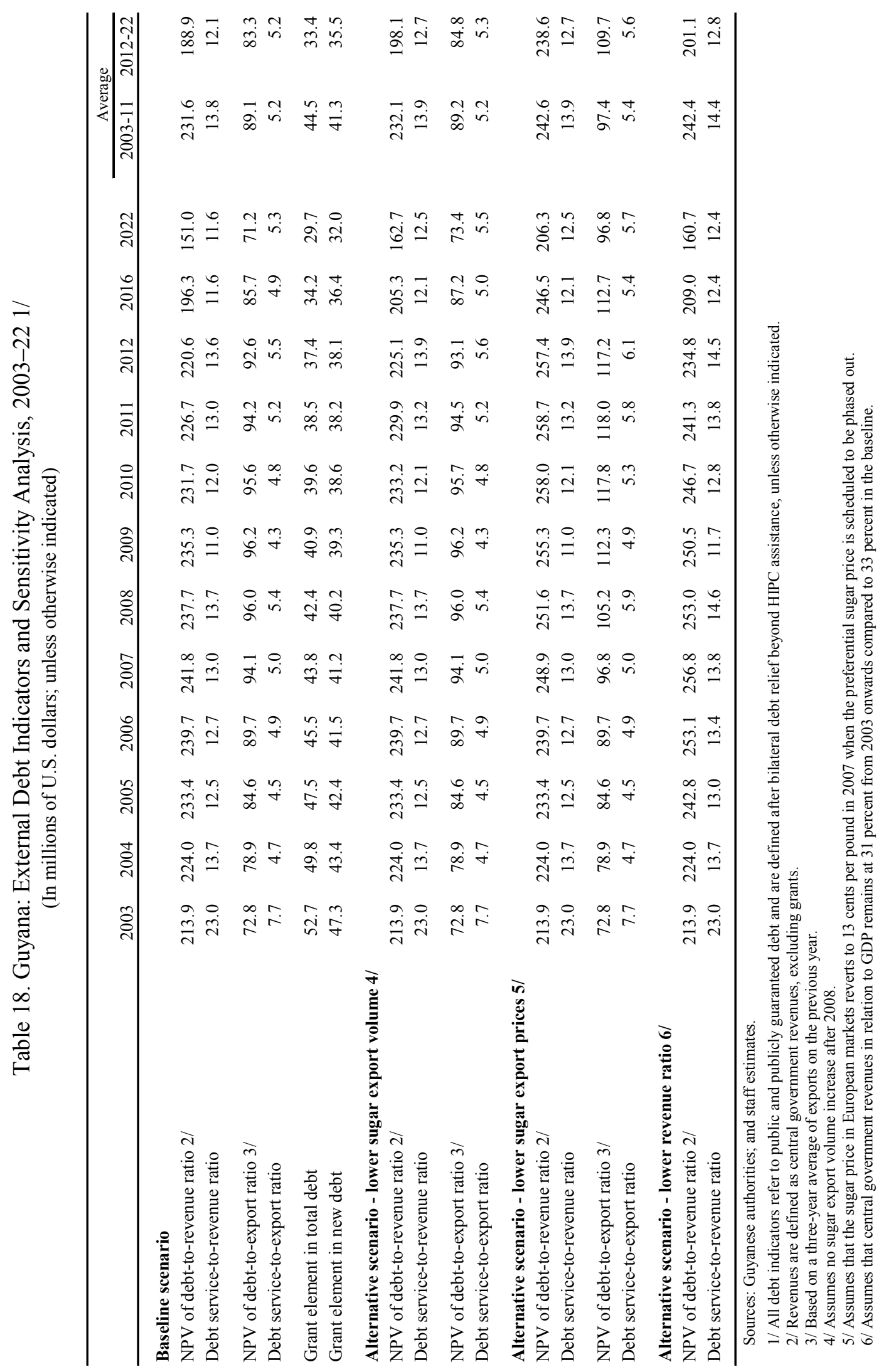




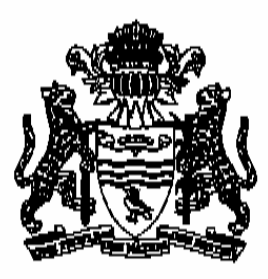

\section{MINISTRY OF FINANCE 49 Main \& Urquhart Streets, Georgetown, Guyana.}

Georgetown, Guyana

November 19, 2003
Mr. Horst Köhler

Managing Director

International Monetary Fund

Washington, D.C. 20431

U.S.A.

Dear Mr. Köhler:

In September 2003, the IMF's Executive Board concluded Guyana's first review under current Poverty Reduction and Growth Facility (PRGF) arrangement, and Directors noted that Guyana had maintained macroecomomic stability while making substantial progress in the implementation of most of the completion point triggers under the Enhanced Heavily Indebted Poor Countries initiative (E-HIPC). In light of the completion of the first review and Guyana's satisfactory track record of policy implementation under the PRGF arrangement, and the successful implementation of many of the policies elaborated in the Poverty Reduction Strategy Paper (PRSP) over the last year, the government of Guyana now wishes to advance towards the attainment of the completion point, under the Enhanced HIPC initiative, in December 2003.

As noted above, by September 2003 , almost all the completion point trigger conditions had been met, but there were two exceptions, both associated with civil service reform.

- With respect to the reduction of 1,000 persons in the core civil service, it was felt that given the ethnic composition of the civil service, the strong efforts needed to obtain this objective would have resulted increased ethnic tensions and significant risks to the social and political stability of the country. This notwithstanding, the Government was able to take compensatory measures through efforts to improve efficiency ard lower costs in the overall public sector, which has resulted in a reduction of 2,500 public sector employees, since 2001. The efforts were not envisaged under the original completion point triggers.

- On the commitment to complete staff audits, job descriptions, and a performance appraisal system, while the first objective was completed, the two remaining objectives were changed through a joint decision with the $\mathrm{DB}$, in June 2001. Instead of developing job descriptions and a performance appraisal system, the 
compensatory measures agreed with the IDB, required that the government complete a civil service payroll audit, approve a Public Sector Modernization Program ( PSMP) and finalize the initial design of the PSMP. All government actions contemplated in the reformulated program have been fully completed.

To further strengthen civil service reform, the government has tightened its existing hiring freeze, with respect to employment in the core civil service, beginning October 2003, and this will remain in place for two years until the IDB program becomes operational. Also, the government will enact in early December, a revised Fiscal Management and Accountability Act, designed to strengthen the regulatory framework for the preparation and execution of the annual budget and which will also provide a more transparent and efficient financial management system for the Central Government and its semiautonomous agencies.

As noted above, important progress was made on the full implementation of most of the floating completion point trigger conditions, a satisfactory track record of policy implementation exists under the PRGF arrangement, and the government's remains strongly committed to civil service reform, over the remaining years of the current arrangement, and into the long term. Given that where certain completion point trigger conditions could not have been met, significant compensatory measures were taken, the government of Guyana requests waivers for the nonobservance of the following floating completion point triggers;

a. Separate from the core civil service 1,000 temporary and unqualified civil servants.

b. Complete staff audits, job description and a performance appraisal system to fulfill the technical assistance component of a comprehensive public sector modemization program.

The Government of Guyana remains committed to the major objectives of poverty reduction and sustainable growth as outlined in our Poverty Reduction Strategy Paper (PRSP), and incorporated in ow PRGF-supported program, and we look forward to continued support from the IMF in our pursuit of these two important objectives.

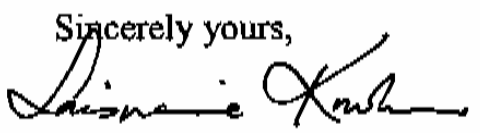

Saisnarine Kowlessar

Minister of Finance 


\section{DebT Management}

Guyana's debt-monitoring system tracks medium- and long-term public and publicguaranteed debt on a loan-by-loan basis although the data processing capacity has some shortcomings. The debt monitoring tasks are divided between the ministry of finance which handles Guyana's external debt and the Bank of Guyana which monitors the domestic debt.

A committee comprising of representatives from the ministry of finance, the Bank of Guyana, and the ministry of foreign affairs meets on an ad hoc basis to discuss debt strategy although the debt management function is not yet integrated into macroeconomic policy making. The authorities are planning to enhance their capacity to make medium term macroeconomic projections and will use the results of the debt sustainability analysis performed in conjunction with this completion point document as a starting point for regular debt strategy meetings.

The data management capacity of the external debt statistics could be enhanced with extra resources and technical support. The data is currently stored in excel spreadsheets and therefore the debt management unit would benefit from funds to install the latest version of the Commonwealth Secretariat database system CS-DRMS for data management and the analytical software Debt-Pro to carry out debt sustainability analyses. Staff is trained in basic debt management functions although there is a shortage of specialists with analytical skills. The skill base is enhanced by a repeated two-year economist secondment from DFID.

While the debt unit methodically evaluates the concessionality of any new external loan that is being considered, consistent with the condition on eliminating nonconcessional borrowing, it does not play a coordinating role in new borrowing. As a result, the roles of the various government institutions in contracting new borrowing is unclear as is the role of the Accountant General's Department in debt management. To rectify this problem, the ministry of finance must take a leading coordinating role in future and assess in detail the impact of new loans on the overall debt portfolio. 